\title{
11. BENTONITIC CLAYS AS INDICATORS OF EARLY NEOCOMIAN POST-BREAKUP VOLCANISM OFF NORTHWEST AUSTRALIA ${ }^{1}$
}

\author{
Ulrich von $\operatorname{Rad}^{2}$ and Jürgen Thurow ${ }^{3}$
}

\begin{abstract}
Bentonites (i.e., smectite-dominated, altered volcanic ash layers) were recovered in Berriasian to Valanginian hemipelagic sediments of the Wombat Plateau (Site 761) and southern Exmouth Plateau (Site 763). They are compared to coeval bentonites in eupelagic sediments of the adjacent Argo Abyssal Plain (Sites 261 and 765) and Gascoyne Abyssal Plain (Site 766).

A volcaniclastic origin with dacitic to rhyolitic ash as parent material is suggested by the abundance of well-ordered montmorillonite, fresh to altered silicic glass shards, volcanogenic minerals (euhedral sanidine, apatite, and long-prismatic zircon), and volcanic rock fragments, and by a vitroclastic ultrafabric (smectitized glass shards). We distinguish (1) pure smectite bentonites with a white, pink, or light gray color, a waxy appearance, and a very homogeneous, cryptocrystalline smectite matrix (water-free composition at Site 761: $68.5 \% \mathrm{SiO}_{2}, 0.27 \% \mathrm{TiO}_{2}, 19.1 \% \mathrm{Al}_{2} \mathrm{O}_{3}, 3.3 \% \mathrm{Fe}_{2} \mathrm{O}_{3}, 0.4 \%-1.1 \% \mathrm{Na}_{2} \mathrm{O}$, and $0.6 \% \mathrm{~K}_{2} \mathrm{O}$ ) and (2) impure bentonitic claystones containing mixtures of volcanogenic smectite and pyroclastic grains with terrigenous and pelagic components.

The ash layers were progressively altered during diagenesis. Silicic glass was first hydrated, then slightly altered (etched with incipient smectite authigenesis), then moderately smectitized (with shard shape still intact), and finally completely homogenized to a pure smectite matrix without obvious relict structures. Euhedral clinoptilolite is the latest pore-filling or glass-replacing mineral, postdating smectite authigenesis.

Volcanic activity was associated with continental breakup and rapid subsidence during the "juvenile ocean phase." Potential source areas for a Neocomian post-breakup volcanism include the Wombat Plateau, Joey and Roo rises, Scott Plateau, and Wallaby Plateau/Cape Range Fracture Zone. Westward-directed trade winds transported silicic ash from these volcanic source areas to the Exmouth Plateau into the adjacent abyssal plains. The Wombat Plateau bentonites are interpreted as proximal ash turbidites.
\end{abstract}

\section{INTRODUCTION}

One of the most exciting but poorly understood themes of passive margin evolution is the study of the tectonic, volcanic, and sedimentary environment following continental breakup at the margin and the formation of a "juvenile ocean" in the adjacent rapidly subsiding, laterally growing, restricted proto-oceanic basins (e.g., von Rad and Exon, 1983). During Ocean Drilling Program (ODP) Leg 122, we recovered a significant terrigenous to hemipelagic "juvenile ocean" sequence of early Neocomian age at Site 761 on the Wombat Plateau (Fig. 1), a section which contained a number of bentonite layers in addition to other conspicuous lithofacies such as belemnite-rich sands and calcisphere nannofossil chalks (Haq, von Rad, O'Connell, et al., 1990; Bralower, this volume). Leg 123 discovered similar, coeval bentonitic clays in the adjacent Argo Abyssal Plain Site 765 in a sequence dominated by pelagic claystone with radiolarites and carbonate turbidites (Ludden, Gradstein, et al., 1990; Thurow and von Rad, in press). The bentonite layers in these drill sites are the first discoveries of an important early Neocomian phase of "post-breakup volcanism" (von $\mathrm{Rad}$ et al., 1989). While there is extensive literature on volcanogenic sedimentation in back-arc basins (Carey and

\footnotetext{
${ }^{1}$ von Rad, U., Haq, B. U., et al., 1992. Proc. ODP, Sci. Results, 122 College Station, TX (Ocean Drilling Program).

2 Bundesanstalt für Geowissenschaften und Rohstoffe, Postfach 510153, D-3000 Hannover 51, Federal Republic of Germany.

${ }^{3}$ Institut und Museum für Geologie und Palăontologie, Universitāt Tübingen, Sigwartstr. 10, D-7400 Tübingen, Federal Republic of Germany. (Present address: Institut für Geologie der Ruhr-Universităt, Postfach 102148, D-4630 Bochum, Federal Republic of Germany.)
}

Sigurdson, 1984; von Rad and Mühe, 1990), the phenomenon of volcaniclastic deposition at divergent plate boundaries (passive margins) just after continental breakup has received very little attention.

The objectives of this paper are:

1. To describe the composition of bentonite layers using optical mineralogy, scanning electron microscopy, geochemistry, and clay mineralogy;

2. To describe the facies association and the fabric of the bentonite layers;

3. To discuss the occurrence of bentonites off northwest Australia in the framework of the plate-tectonic and paleogeographic setting (Fig. 2), and

4. To draw preliminary conclusions as to the type and significance of early Neocomian post-breakup volcanism off northwest Australia (source areas, mode of deposition, redeposition, and alteration of the ash layers).

A companion paper (Thurow and von Rad, in press) will describe and interpret the Leg 123 bentonites in more detail.

In this paper, we use the term "bentonite" loosely, as suggested by Grim and Güven (1978), Fisher and Schmincke (1984), and Schmincke (1989): bentonites are smectite-dominated clays that originated as volcanic ash layers, mostly of rhyolitic to dacitic composition, and which have been more or less completely altered ("argillized") in situ into smectite in a subaqueous environment. Submarine bentonites are distinct, usually thin layers, generally characterized by wide lateral extent, vitroclastic texture, the presence of euhedral (hightemperature) minerals (e.g., sanidine, biotite, zircon, and apatite), and a chemical composition derived from volcanic source material (see also Zimmerle, 1989). 


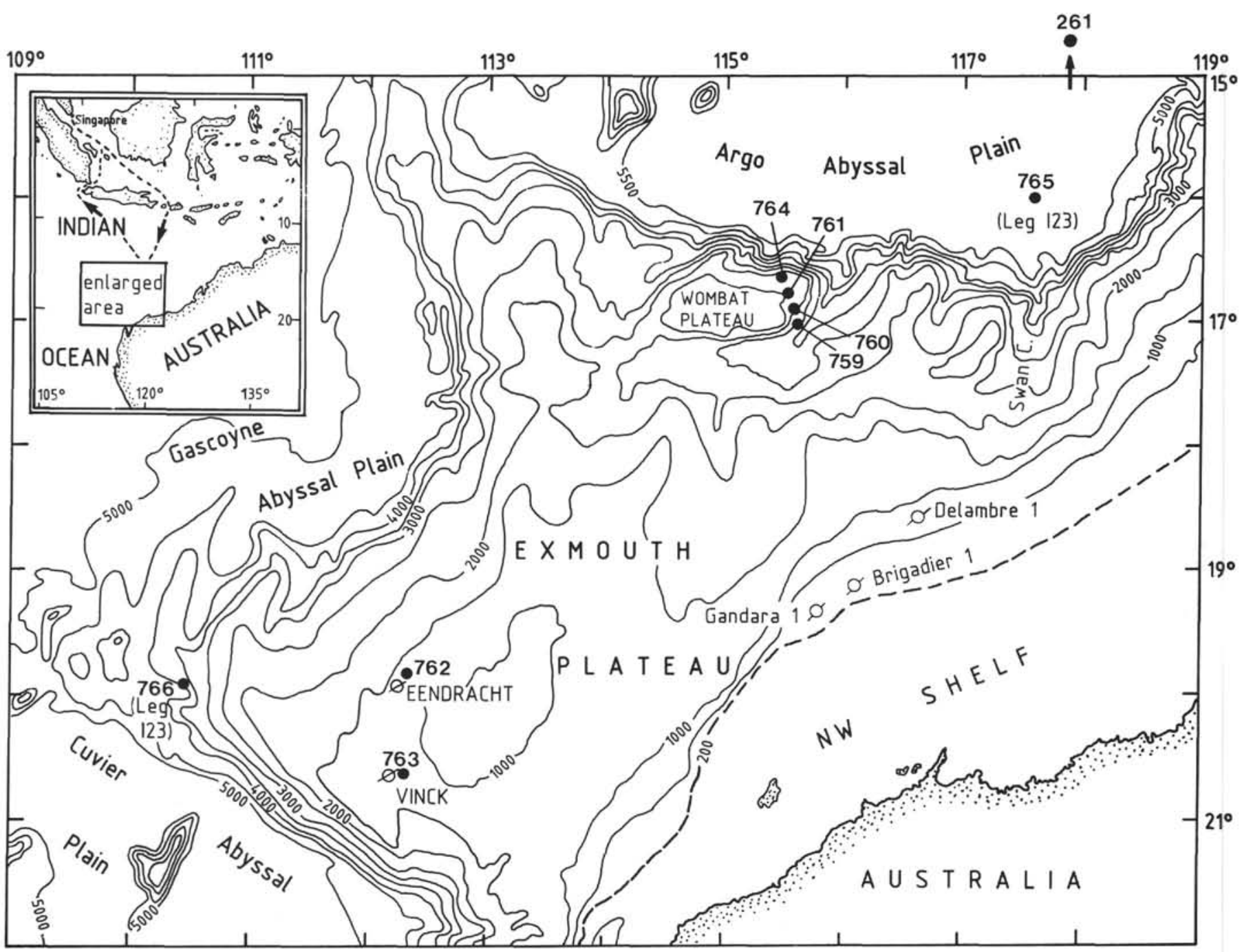

Figure 1. Location of ODP Legs 122 and 123 sites and commercial well sites on the Exmouth Plateau and vicinity. DSDP Leg 27 Site 261 (Veevers, Heirtzler, et al., 1974) is also shown. The ocean/continent boundary coincides roughly with the steep escarpment between the Exmouth Plateau (continental crust) and the surrounding deep ocean basins (Argo, Gascoyne, and Cuvier abyssal plains). Bathymetry in meters.

The "bentonites" of Legs 122 and 123 can be subdivided into (1) "pure smectite bentonites" containing only trace amounts of pelagic and nonvolcanic terrigenous components and (2) "impure bentonites" comprising a wide range of mixtures of volcanogenic smectite and pyroclastic grains with nonvolcanic (terrigenous and pelagic) components (see section on Wombat Plateau bentonites).

\section{METHODS}

Lithostratigraphic study of Site 761 was supplemented by downhole geophysical logs; in particular, natural gammaradioactivity logs, thorium (and potassium) spectral logs, and sonic velocity logs were useful in delineating bentonitic clays, sands, and cherts (Fig. 3).

We investigated the lithogenesis of about 80 "bentonite" samples (Leg 122 and 123) by integrated optical mineralogical methods, X-ray diffraction (XRD) analysis, X-ray fluorescence (XRF) geochemistry, and scanning electron microscopy (SEM), as suggested by Zimmerle (1989) (Tables 1-3). Optical mineralogy was performed using smear slides of bulk material and highly polished, 10- $\mu$ m-thick thin sections (Dr. Zinkernagel, Bochum). Most bentonite samples were processed with $\mathrm{H}_{2} \mathrm{O}_{2}$ and ultrasonic vibration, and sieved through $32-$ and $63-\mu \mathrm{m}$ screens; in some samples the $<2-\mu \mathrm{m}$ fraction was separated by the Atterberg method (settling tube) or centrifuging. The $>32-\mu \mathrm{m}$ (or $>63-\mu \mathrm{m}$ ) fractions were investigated under the microscope as coarse fraction mounts. The refractive indexes of volcanic glass were measured using immersion liquids. From 16 specially selected coarse fractions, the heavy mineral fractions (density $>2.94 \mathrm{~g} / \mathrm{cm}^{3}$ ) were separated by tetrabromine-ethane and the heavy and light mineral fractions mounted in acrochlor $(n=$ $1.665)$ and canada balsam ( $n=$ about 1.54$)$, respectively.

XRD analysis was performed on about 80 samples, mostly from the $<2-\mu \mathrm{m}$ or $<32-\mu \mathrm{m}$ fractions at the Bundesanstalt für Geowissenschaften und Rohstoffe (BGR) at Hannover and at the Geologisches Institut, University of Tübingen (Philipps $\mathrm{X}$-ray diffractometer, $\mathrm{CuK} \alpha$-radiation with $\mathrm{Ni}$ filter in Tübingen and graphite monochromator at BGR in Hannover, $35 \mathrm{kV}$, $20 \mathrm{~mA}$ ). Our semiquantitative XRD results are shown in Table 1. Special XRD investigations were performed with $\mathrm{CoK} \alpha$ radiation, a count rate of 0.01 or 0.02 degrees per second (s), and a count time of $2 \mathrm{~s}$ at the Alfred-Wegener Institut at Bremerhaven (R. Petschick, see Fig. 4).

Geochemical (XRF) analysis of 12 major and 24 trace elements was obtained from 30 selected samples (XRF laboratory at BGR; see Tables 2 and 3 ). 

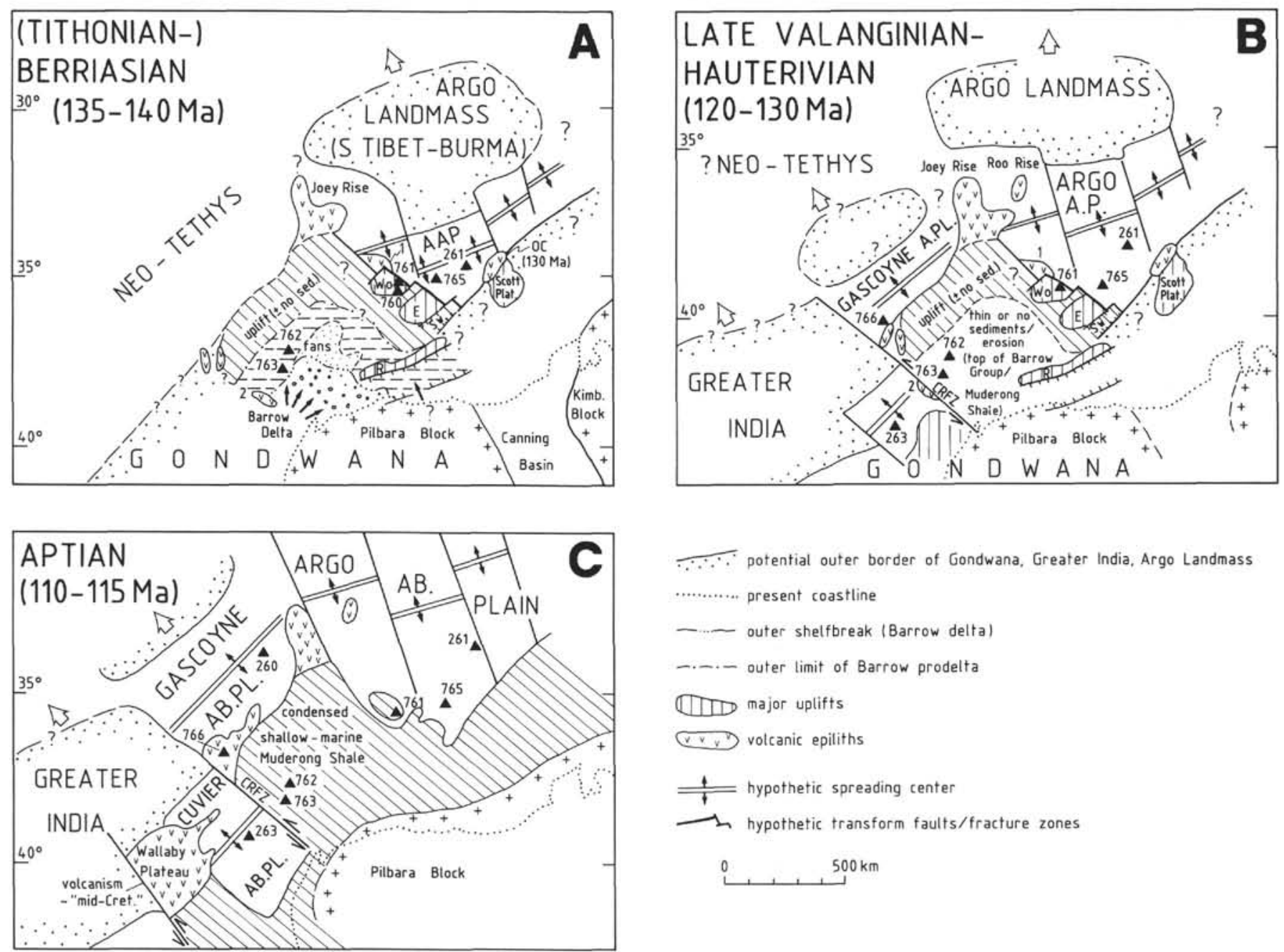

Figure 2. Paleogeography of the northwest Australian margin and vicinity during the Tithonian to Aptian. Modified from Barber (1982), Exon et al. (this volume), Kopsen and McGann (1985), Bradshaw et al. (1988), Veevers (1988), Boote and Kirk (1989), Gradstein et al. (1989), and Boyd et al. (this volume). Paleolatitudes after Ogg et al. (in press). A. Tithonian to Berriasian. B. Late Valanginian to Hauterivian. C. Aptian. Abbreviations: $\mathrm{AAP}=$ Argo Abyssal Plain, $\mathrm{CRFZ}=$ Cape Range Fracture Zone, $\mathrm{E}=\mathrm{Emu}$ Plateau, OC $=$ Oates Canyon (western escarpment of Scott Plateau), $\mathrm{R}=$ Rankin Platform, $\mathrm{Sw}=$ Swan Canyon graben, Wo $=$ Wombat Plateau (transgressive Berriasian sand and calcisphere/bentonite series); 1 = Rhaeto-Liassic older volcanics (northern Wombat escarpment), 2 = mid-Berriasian intrusion (Boyd et al., this volume).

SEM analysis of about 30 selected bulk samples and some coarse fractions or hand-picked minerals was performed by both authors, mainly at the Tübingen institute, partly also at BGR. These analyses provide important insights into the ultrafabric, the detrital, volcanogenic, and authigenic minerals, and the fossils of the investigated bentonites. The application of the energy-dispersive X-ray fluorescence (EDX) analysis allowed also the chemical determination and mineralogical identification of unknown components (Pl. 4).

\section{GEOLOGICAL AND STRATIGRAPHIC SETTING OF LEG 122/123 BENTONITES}

Bentonitic clays were found in Berriasian-Valanginian sections of ODP Sites 761, 763, 765, and 766, and Deep Sea Drilling Project (DSDP) Site 261 (Fig. 1). We will briefly describe the geological and structural setting of these drill sites (see also Haq, von Rad, O'Connell, et al., 1989; Ludden, Gradstein, et al., 1990; von Rad et al. 1989; Thurow and von Rad, in press).

\section{Site 761}

Site 761 on the Wombat Plateau, a small subplateau of the northern Exmouth Plateau, penetrated a very thin $(<30 \mathrm{~m})$ "juvenile ocean" section of terrigenous to hemipelagic sediments overlying a marked "post-rift unconformity." This unconformity is underlain directly by Upper Triassic (Rhaetian) syn-rift platform carbonates (Röhl et al., this volume). Figure 3 shows a lithostratigraphic column of this "juvenile ocean section." Because of the comparatively poor core recovery of Holes $761 \mathrm{~B}$ and $761 \mathrm{C}$, we used the continuous record of the in-situ petrophysical and geochemical properties measured by wireline logs (i.e., natural gamma-ray, thorium (Th), natural gamma-ray spectrometry (NGT), and sonic velocity) to supplement the cored section. The wireline logs also helped to interpret the depositional environment and sea-level fluctuations (Boyd and Bent, this volume). The sequence shown in Figure 3 contains: 


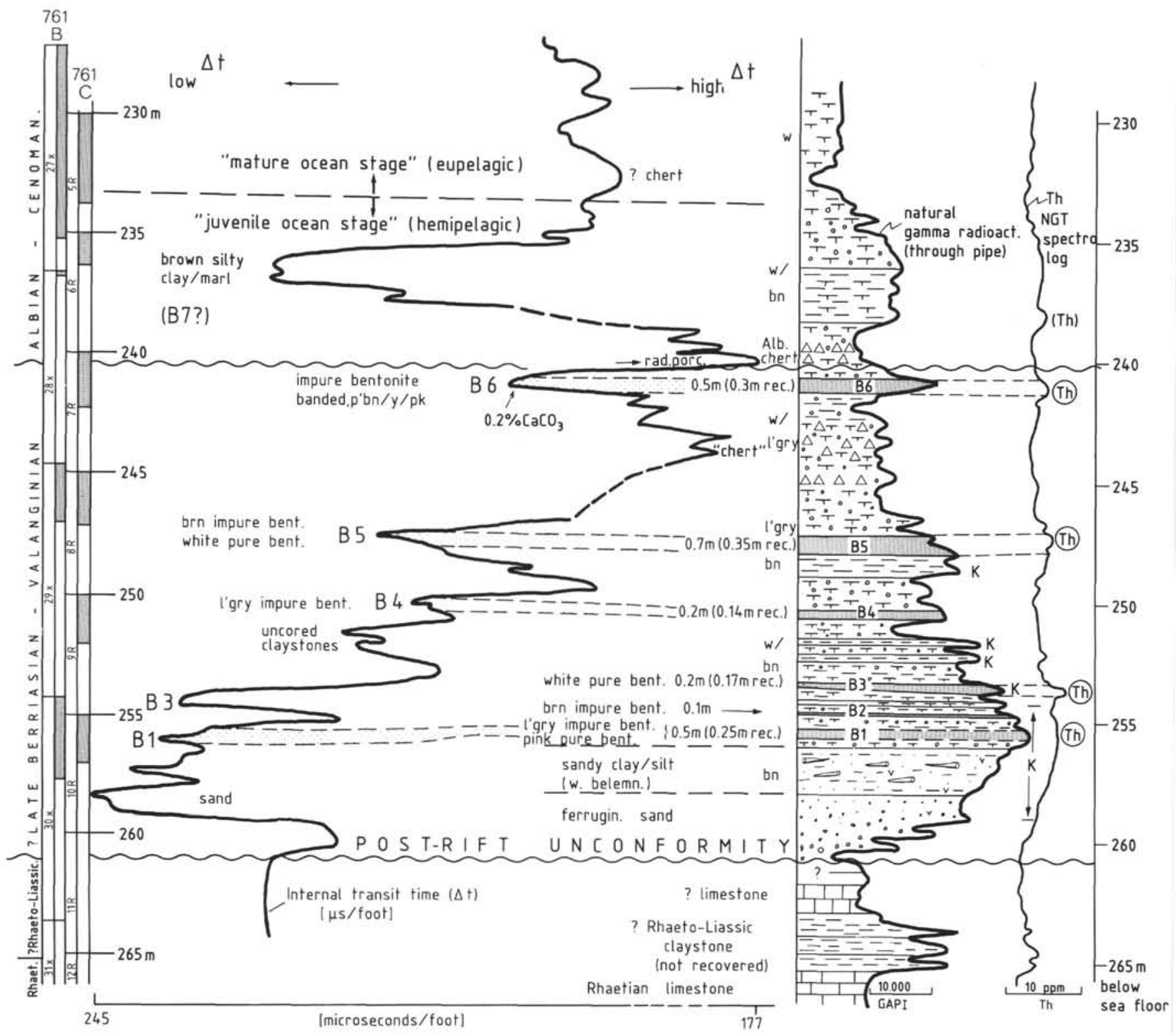

Figure 3. Lithostratigraphy of the Lower Cretaceous section at Site 761 (Wombat Plateau) correlated with wireline logs (sonic velocity, natural gamma radioactivity, thorium, and natural gamma-ray spectrometry, or NGT). Note the good correlation of the six bentonite layers (B1-B6) and a few uncored claystone intervals with natural gamma-ray maxima, high Th contents, and low-velocity intervals. $\mathrm{K}$ designates peaks of other "claystones" from the K-NGT spectrometry log. "Chert" (porcellanite) horizons show the opposite trend (sonic velocity maxima and gamma-ray log minima). Note that due to the limited core recovery (lefthand column) the lithostratigraphic column is largely based on log interpretation. See text for further discussion.

1. A 5-m-thick, fining upward (i.e., deepening upward) condensed section of ferruginous sand grading into a belemnite-rich sandy silt/clay. This sequence, which shows rapidly increasing natural gamma ray and decreasing sonic velocity values, is interpreted as a transgressive (?littoral to nearshore) sand deposited under high-energy conditions and derived from reworking the Upper Triassic siliciclastic sediments exposed in the area of Site 760 on the uplifted Wombat block (von Rad et al., this volume). The belemnite sandy silt/clay was deposited in a low-energy shelf setting at very low sedimentation rates. This sequence is roughly similar to the Birdrong Sandstone of the Carnarvon Basin (Hocking et al., 1987). This formation, however, is somewhat younger (Valanginian to Barremian) and is a coastal to nearshore, diachronous deposit of a few tens of meters formed during the Neocomian transgression.

2. A $25-\mathrm{m}$-thick section dominated by hemipelagic calcisphere nannofossil chalk and marl, intercalated with porcellanite nodule horizons (240-246 meters below seafloor, or mbsf) and (at least) six conspicuous bentonite horizons, called B1-B6; the bentonitic claystones (and a brown silty marl/clay at 237 mbsf, possibly also a bentonite) are characterized by relatively low sonic velocities and gamma-ray maxima. Gamma-ray maxima plus thorium maxima mark bentonite layers because montmorillonite contains up to 59 parts per million (ppm) Th. The water depth during this interval probably had increased by rapid early post-breakup subsidence to bathyal depths (about 200-1000 m). This sequence might correlate 
Table 1. Sample data, age, color, "bentonite number," fabric, rock name, optical mineralogy, and XRD and SEM analysis data of all investigated bentonitic claystones (Legs 122 and 123).

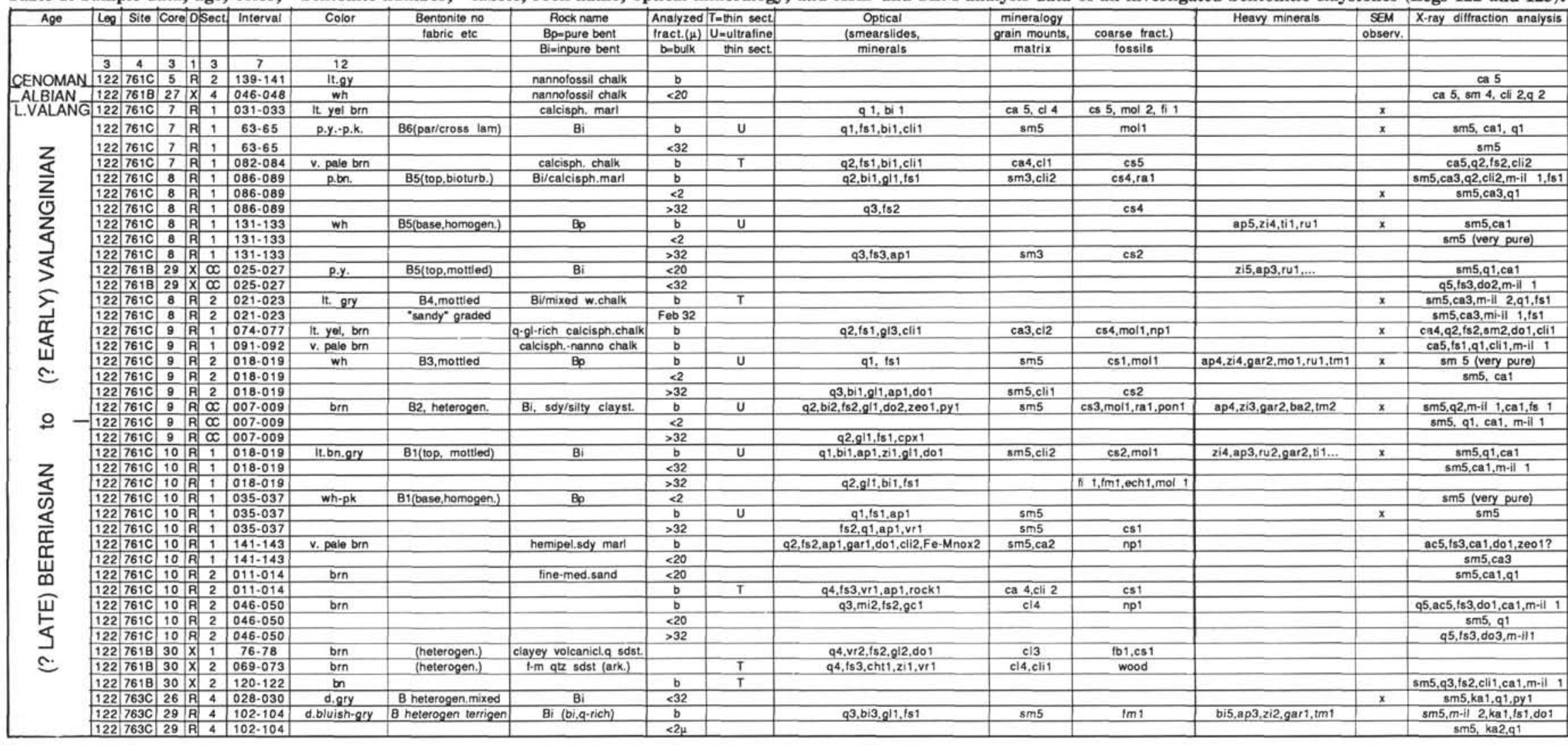

Note: General abbreviations: $\mathrm{Bp}=$ pure bentonite $=$ almost $100 \%$ smectite, $\mathrm{Bi}=$ impure bentonite $=$ dominant smectite + hemipelagic material $($ mixed volcanic, terrestrial, authigenic, and pelagic material). Abundance (XRD): $5=$ abundant $(>50 \%), 4=$ common $(25 \%-40 \%), 3=$ present $(10 \%-25 \%), 2=$ few $(2 \%-16 \%), 1=$ rare $($ traces, $<2 \%)$. Color: wh $=$ white, pk $=$ pink, rd $=$ red, b-rd $=$ brick-red, $y=$ yellow, gry $=$ gray, grn $=$ green, $b n=$ brown, It $=$ light, $d k=$ dark., $v=$ very, $p=$ pale. Minerals, matrix, and rocks: $\mathrm{ca}=$ calcite, $\mathrm{cl}=$ undifferentiated clay minerals, do $=$ dolomite, $\mathrm{q}=\mathrm{quartz}, \mathrm{fs}=$ feldspar, $\mathrm{m}=$

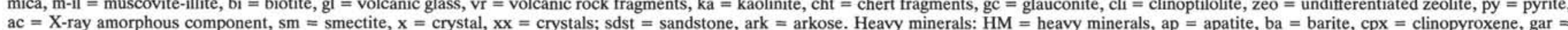
garnet, $\mathrm{mo}=$ monacite, $\mathrm{ru}=$ rutile, $\mathrm{t} i=$ titanite, $\mathrm{tm}=$ tourmaline, $\mathrm{zi}=$ zircon. Fossils: $\mathrm{cs}=$ calcispheres, ech $=$ echinoderms, $\mathrm{fi}=$ fish debris, mol $=$ molluscs, $\mathrm{np}=$ nannoplankton $($ coccoliths $)$, pon $=\mathrm{spong}$ spicules, $\mathrm{ra}=$ radiolarians. 
Table 2. Chemical composition (major and minor elements, XRF analysis) of all investigated pure bentonites (Bp) and impure bentonitic clays (Bi).

\begin{tabular}{|c|c|c|c|c|c|c|c|c|c|c|c|c|c|c|c|c|c|c|c|c|}
\hline Leg & Site & Core & D & Sect. & Interval & Lab.-No. & Color & Size & Purity & $\mathrm{SiO} 2 \%$ & TiO2 \% & $\mathrm{Al} 2 \mathrm{O} 3$ & $\mathrm{Fe} 2 \mathrm{O} 3$ & $\mathrm{MnO} \%$ & $\mathrm{MgO} \%$ & $\mathrm{CaO} \%$ & $\mathrm{Na} 2 \mathrm{O} \%$ & $\mathrm{~K} 2 \mathrm{O} \%$ & P2O5 \% & O3) $\%$ \\
\hline & & & & & (cm) & & & $(\mu \mathrm{m})$ & & & & & & & & & & & & \\
\hline 122 & $761 B$ & 29 & $\mathrm{x}$ & $\propto$ & $025-027$ & 87130 & It.gry & $<20$ & Bi (B5) & 67,04 & 0,19 & 19,11 & 2,60 & 0,01 & 7,14 & 0.73 & 2,04 & 0,88 & 0,04 & 0,05 \\
\hline 122 & $761 \mathrm{C}$ & 7 & R & 1 & 063.065 & 87121 & $g n / p k$ & $<32$ & $\mathrm{Bi}(\mathrm{B} 6)$ & 60,03 & 0,50 & 16,33 & 6,33 & 0,01 & 6,99 & 1,36 & 3,04 & 0,97 & 0,05 & 0,16 \\
\hline 122 & $761 \mathrm{C}$ & 8 & R & 1 & $131 \cdot 133$ & 87123 & wh/lt.gry & $<32$ & Bp (B5) & 68,66 & 0,19 & 19,73 & 2,64 & 0,01 & 6,95 & 0,63 & 0,39 & 0,54 & 0,04 & 0,05 \\
\hline 122 & $761 \mathrm{C}$ & 8 & R & 2 & 021.023 & 87124 & It. gry & $2 \cdot 32 \mu$ & $\mathrm{Bi}(\mathrm{B} 4)$ & 66,18 & 0,26 & 18,49 & 2.74 & 0,01 & 6,41 & 3,19 & 1,34 & 1,01 & 0,05 & 0.07 \\
\hline 122 & $761 \mathrm{C}$ & 9 & R & 2 & $018-019$ & 87125 & wh & $<32$ & $\mathrm{Bp}(\mathrm{B} 3)$ & 68,78 & 0,31 & 18,80 & 3,40 & 0,01 & 6,57 & 0.71 & 0,42 & 0,65 & 0,04 & 0,08 \\
\hline 122 & $761 \mathrm{C}$ & 9 & R & $\propto$ & 007.009 & 87126 & brn & $<32$ & $\mathrm{Bi}(\mathrm{B} 2)$ & 62,85 & 2,08 & 14,58 & 11,29 & 0,34 & 4,47 & 1,18 & 0,27 & 2,49 & 0,09 & 0,08 \\
\hline 122 & $761 \mathrm{C}$ & 10 & R & 1 & 018.019 & 87127 & gry & $<32$ & $\mathrm{Bi}$ (B1) & 67,81 & 0,35 & 17,99 & 4,03 & 0,35 & 6,09 & 1,88 & 0,29 & 0,78 & 0,05 & 0.04 \\
\hline 122 & $761 \mathrm{C}$ & 10 & R & 1 & $035-037$ & 87128 & pk & $<2$ & $\mathrm{Bp}(\mathrm{B} 1)$ & 68,06 & 0,31 & 18,69 & 3,77 & 0,02 & 6,74 & 0,30 & 1,12 & 0,61 & 0,05 & 0.11 \\
\hline 122 & $763 \mathrm{C}$ & 26 & R & 4 & $028-030$ & 87131 & dk.gry & & $\mathrm{Bi}$ & 59,87 & 0,28 & 9 & 9,31 & .01 & .03 & 0,85 & 0,10 &, 28 &, 10 & 0,21 \\
\hline 122 & $763 C$ & 29 & R & 4 & $102-104$ & 87132 & dk.bl.gry & & $\mathrm{Bi}$ & 56,01 & 0,54 & 26,40 & 10,86 & .02 & 2,74 & 1,21 & 0,29 & 1,17 & 0,19 & 0,40 \\
\hline 123 & $766 \mathrm{~A}$ & 48 & R & 2 & & & dk. gry & $<2$ & $\mathrm{Bi}$ & & & & & 1 & & 1,27 & & .29 & & 0,22 \\
\hline 123 & $766 \mathrm{~A}$ & 48 & $\mathrm{R}$ & 2 & $142 \cdot 147$ & 87146 & & b & $\mathrm{Bi}$ & 63,16 & 0,23 & 18,73 & 8,77 & 0,01 & 4,34 & 1,18 & 2,59 & .49 & 0.05 & 0,47 \\
\hline 123 & $766 \mathrm{~A}$ & 48 & $\mathrm{R}$ & 4 & 078.081 & 87147 & dk. gn & b & $\mathrm{Bi}$ & 62,03 & 0,72 & 17,80 & 8,88 & 0,01 & 3,74 & 1,97 & 2,34 & ,63 & 0,09 & 0,92 \\
\hline 123 & $765 \mathrm{C}$ & 58 & R & 5 & 1 & & It & & & & 0,82 & & 5 & 9 & & 0 & & 1 & 6 & 15 \\
\hline 123 & $765 \mathrm{C}$ & 59 & $\mathrm{R}$ & 3 & 094-096 & 88894 & It $g y>>1 t$ gn & & & 63,84 & 1,42 & 20,42 & 2,19 & 0,10 & 3,43 & 1,52 & 2,25 & 63 & 21 & 0,52 \\
\hline 123 & $765 \mathrm{C}$ & 60 & R & 1 & $084-086$ & 88227 & & & & 69,88 & 0,70 & 14,07 & 5,57 & 0,26 & 2,99 & 1,14 & 1,22 & 3,04 & 1 & 0,11 \\
\hline 123 & $765 \mathrm{C}$ & 60 & R & 1 & $112 \cdot 115$ & 87133 & brn-rd & b & & 71,52 & 0,54 & 11,66 & 8,00 & 0,16 & 2,29 & 5 & 1,28 & 34 & 9 & 0,14 \\
\hline 123 & $765 c$ & 60 & $\mathrm{R}$ & 1 & $120-123$ & 87134 & & b & & 71,94 & 0,60 & 12,25 & 5,85 & 0,20 & 2,44 & 1,60 & 1,24 & 2,72 & 9 & 0,23 \\
\hline 123 & $765 \mathrm{C}$ & 60 & R & 3 & 016.020 & 88895 & gn-gy $\gg$ red bn & & & 3 & 1, & 14 & 5,64 & 0,08 & 6 & 9 & & 4 & 3 & 0,17 \\
\hline 123 & $765 \mathrm{C}$ & 60 & R & 3 & 061.064 & 88896 & It gn $\gg>$ d bn & & & 64,50 & 0,56 & 20,45 & 2,14 & 0,14 & 5,33 & 1,70 & 3 , & 0,70 & 0,03 & 0,18 \\
\hline 123 & $765 \mathrm{C}$ & 60 & R & 4 & 03 & 8 & $g n(r d)$ & b & & 9 & $0, \epsilon$ & & 6,46 & 0 & 2,7 & & & & 2 & 0,14 \\
\hline 123 & $765 \mathrm{C}$ & 60 & R & 5 & $061-064$ & 8 & $\mathrm{rd} / \mathrm{gn}$ & $<20$ & & 67,41 & 0.6 & 19,82 & 2,55 & 1 & 4,70 & 7 & 1. & 1,01 & .06 & 0,05 \\
\hline 123 & $765 \mathrm{C}$ & 60 & R & 5 & $116-119$ & 8 & gry-gn & $<2$ & & & 9 & 20 & 3,37 & 0,05 & 5 & 5 & 0 & & 4 & 0,18 \\
\hline 123 & $765 \mathrm{C}$ & 60 & R & 5 & 119 & 88897 & only It gn & & & 2 & 0,24 & 19,94 & 1,90 & 0,08 & 6,04 & 6 & 2. & 1 & 0,05 & 0.10 \\
\hline 123 & $765 \mathrm{C}$ & 60 & R & 5 & $120-123$ & 87138 & & $<20$ & & 67,22 & 0,20 & 21,20 & 0,83 & 0,09 & 5,86 & 1,46 & 2,44 & 36 & 4 & 0,10 \\
\hline 123 & $765 \mathrm{C}$ & 61 & R & 1 & $033-036$ & 87141 & $b-r d$ & & & 66,49 & 0.87 & 14,43 & 8,50 & 0,38 & 7 & 0,82 & 1,56 & 2 & 3 & 0,17 \\
\hline 123 & $765 \mathrm{C}$ & 61 & R & 1 & 050.052 & 88898 & red bn>>lt gn & & & 63,74 & 0,76 & 16,84 & 7.54 & 0,09 & 4,60 & 1,34 & 2,13 & 2,05 &, 20 & 0,10 \\
\hline 123 & $765 \mathrm{C}$ & 61 & R & 1 & 061.064 & 87139 & & & & 65,61 & 0,41 & 18,68 & 3,92 & 0,05 & 9 & 1,35 & 2.92 & 0,63 & .06 & 0,18 \\
\hline 123 & $765 \mathrm{C}$ & 61 & R & 1 & 061.064 & 87140 & It. gry \& rd & $<2$ & & 67,86 & 0,41 & 19,43 & 3,96 & 0,05 & 6,31 & 0,97 & 0.41 & 0,30 & 0,02 & 0,04 \\
\hline 123 & $765 \mathrm{C}$ & 61 & $\mathrm{R}$ & 2 & 052.056 & 88899 & only red bn & & & 64,08 & 1,29 & 14,07 & 10,41 & 0.27 & 2,43 & 1,14 & 1,32 & 4,27 & 0,15 & 0,09 \\
\hline 123 & $765 \mathrm{C}$ & 61 & R & 4 & 071.074 & 88228 & & & & 60,66 & 1,03 & 14,89 & 7,62 & 1,38 & 4,05 & 5 & 1,25 & 1.25 & 0,15 & 0,08 \\
\hline 123 & $765 \mathrm{C}$ & 61 & R & 4 & $079-082$ & 87143 & rd & & & 62,38 & 0. & 15,99 & 7.79 & 0.15 & 4,48 & 3,40 & 2,42 & 1.89 & 0,17 & 0,18 \\
\hline 123 & $765 \mathrm{C}$ & 61 & $R$ & 4 & 079.082 & 87144 & gry & & & 64,81 & 0 . & 17,19 & 4,54 & 0,17 & 5,00 & & 2,06 & 1,83 & 0,15 & 0,16 \\
\hline 123 & $765 \mathrm{C}$ & 61 & $\mathrm{R}$ & 4 & 079.082 & 87148 & gn & $<20$ & & 65,80 & 1,01 & 17,95 & 4,39 & 0,15 & 5,11 & 2,13 & 1,04 & 1,84 & 0,12 & 0,10 \\
\hline 123 & $765 \mathrm{C}$ & 61 & $\mathrm{R}$ & 4 & 079.082 & 87149 & id & $<20$ & & 63,60 & 0.98 & 16,46 & 8.10 & 0,13 & 4,59 & 2,25 & 1,37 & 2,01 & 0,13 & 0,15 \\
\hline
\end{tabular}

Note: Samples were not desalinated ( $\mathrm{Na}_{2} \mathrm{O}$ values are probably too high). For color abbreviations see Table 1 . All major elements calcuiated for LOI-free composition, assuming that most of LOI corresponds to smectite-bound $\mathrm{H}_{2} \mathrm{O}(11 \%-19 \%$, average of all samples $16.7 \%+2.8 \%$, average of pure Wombat bentonites: $17 \%$ LOI). 
Table 3. Chemical composition (minor, or trace, elements, XRF analysis) of all investigated pure bentonites (Bp) and impure bentonitic clays (Bi).

\begin{tabular}{|c|c|c|c|c|c|c|c|c|c|c|c|c|c|c|c|c|c|c|c|c|c|c|}
\hline $\log$ & Site & Core & D & Sect. & Interval & Lab.-No. & Color & Size & Purity & Ba ppm & Ce ppm & Cr ppm & Nb ppm & Ni ppm & $\mathrm{Pb} p p m$ & Rb ppm & Sr ppm & Th ppm & V ppm & Y ppm & Zn ppm & $\mathrm{Zr} \mathrm{ppm}$ \\
\hline & & & & & (cm) & & & $(\mu \mathrm{m})$ & & & & & & & & & & & & & & \\
\hline 122 & $761 \mathrm{~B}$ & 29 & $x$ & $\propto$ & $025-027$ & 87130 & It.gry & $<20$ & $\mathrm{Bi}(\mathrm{B} 5)$ & 50 & 56 & 19 & 12 & 27 & 32 & 12 & 51 & 13 & 27 & $<5$ & 134 & 105 \\
\hline 122 & $761 \mathrm{C}$ & 7 & R & 1 & $063-065$ & 87121 & gn/pk & $<32$ & $\mathrm{Bi}(\mathrm{B} 6)$ & 286 & 107 & 66 & 22 & 57 & 178 & 24 & 57 & 25 & 47 & $<5$ & 233 & 271 \\
\hline 122 & $761 \mathrm{C}$ & 8 & R & 1 & $131-133$ & 87123 & wh/lt.gry & $<32$ & $\mathrm{Bp}(\mathrm{B} 5)$ & 69 & 37 & 27 & 12 & 22 & 43 & 8 & 32 & $<1$ & $<1$ & $<5$ & 153 & 106 \\
\hline 122 & $761 \mathrm{C}$ & 8 & R & 2 & 021.023 & 87124 & It. gry & $2-32 \mu$ & Bi (B4) & 793 & $<35$ & 16 & 10 & 52 & 28 & 21 & 77 & $<1$ & 29 & $<5$ & 148 & 111 \\
\hline 122 & $761 \mathrm{C}$ & 9 & R & 2 & $018-019$ & 87125 & wh & $<32$ & $\mathrm{Bp}(\mathrm{B} 3)$ & 62 & 174 & 15 & 15 & 29 & 24 & 15 & 21 & 59 & $<1$ & 36 & 183 & 294 \\
\hline 122 & $761 \mathrm{C}$ & 9 & R & $\propto$ & $007-009$ & 87126 & brn & $<32$ & $\mathrm{Bi}(\mathrm{B} 2)$ & 450 & 146 & 38 & 26 & 81 & 101 & 91 & 83 & 10 & 61 & 7 & 273 & 258 \\
\hline 122 & $761 \mathrm{C}$ & 10 & R & 1 & 018.019 & 87127 & gry & $<32$ & Bi (B1) & 604 & 208 & 10 & 21 & 80 & 23 & 13 & 70 & 27 & 20 & 77 & 263 & 310 \\
\hline 122 & $761 \mathrm{C}$ & 10 & R & 1 & 035.037 & 87128 & pk & $<2$ & $\mathrm{Bp}(\mathrm{B} 1)$ & 57 & 269 & 27 & 30 & 21 & 29 & 22 & 15 & 48 & 15 & 26 & 344 & 310 \\
\hline 122 & $763 \mathrm{C}$ & 26 & R & 4 & $028-030$ & 87131 & dk.gry & & $\mathrm{Bi}$ & 538 & $<35$ & $<7$ & 13 & 22 & 68 & 6 & 157 & 14 & 23 & $<5$ & 179 & 175 \\
\hline 122 & $763 \mathrm{C}$ & 29 & R & 4 & $102-104$ & 87132 & dk.bl.gry & & $\mathrm{Bi}$ & 650 & 147 & 79 & 18 & 70 & 85 & 32 & 117 & 24 & 32 & 10 & 291 & 403 \\
\hline 123 & $766 \mathrm{~A}$ & 48 & R & 2 & $142 \cdot 147$ & 87145 & dk. gry & $<2$ & $\mathrm{Bi}$ & 99 & 224 & 14 & 60 & 29 & 38 & 7 & 127 & 63 & $<1$ & 55 & 37 & 396 \\
\hline 123 & $766 \mathrm{~A}$ & 48 & R & 2 & $142-147$ & 87146 & & b & $\mathrm{Bi}$ & 61 & 172 & 13 & 58 & 23 & 65 & 10 & 139 & 55 & $<1$ & 47 & 214 & 367 \\
\hline 123 & $766 \mathrm{~A}$ & 48 & $\mathrm{R}$ & 4 & 078.081 & 87147 & dk. gn & b & $\mathrm{Bi}$ & 334 & 202 & 33 & 57 & 47 & 58 & 32 & 140 & 25 & 34 & 80 & 349 & 815 \\
\hline 123 & $765 \mathrm{C}$ & 58 & R & 5 & 099-101 & 88893 & It-gn>>rd & & & 2822 & $<35$ & 70 & 12 & 46 & 26 & 49 & 98 & $<1$ & 98 & 15 & 73 & 133 \\
\hline 123 & $765 \mathrm{C}$ & 59 & $R$ & 3 & $094-096$ & 88894 & It $g y \gg>$ It gn & & & 6463 & 401 & 65 & 72 & 43 & 125 & 40 & 583 & 27 & 22 & 84 & 209 & 1119 \\
\hline 123 & $765 \mathrm{C}$ & 60 & R & 1 & 084.086 & 88227 & & & & 1394 & 123 & 103 & 14 & 88 & 34 & 104 & 107 & 13 & 93 & 32 & 167 & 121 \\
\hline 123 & $765 \mathrm{C}$ & 60 & $R$ & 1 & $112 \cdot 115$ & 87133 & brn-rd & b & & 1659 & 131 & 57 & 12 & 57 & 26 & 81 & 98 & $<1$ & 45 & 35 & 97 & 97 \\
\hline 123 & $765 \mathrm{C}$ & 60 & R & 1 & $120-123$ & 87134 & & b & & 3374 & 178 & 78 & 11 & 67 & 16 & 81 & 136 & $<1$ & 81 & 45 & 104 & 111 \\
\hline 123 & $765 \mathrm{C}$ & 60 & $\mathrm{R}$ & 3 & $016-020$ & 88895 & gn-gy $\gg$ red bn & & & 1748 & 96 & 104 & 14 & 206 & 47 & 93 & 105 & $<1$ & 458 & 22 & 135 & 134 \\
\hline 123 & $765 \mathrm{C}$ & 60 & $\mathrm{R}$ & 3 & 061.064 & 88896 & It $g n \gg>r d b n$ & & & 1783 & $<35$ & 59 & 16 & 178 & 33 & 21 & 152 & 26 & 3100 & 13 & 215 & 381 \\
\hline 123 & $765 \mathrm{C}$ & 60 & $\mathrm{R}$ & 4 & 032.036 & 87135 & gn (rd) & b & & 1945 & 162 & 68 & 14 & 76 & 32 & 92 & 102 & $<1$ & 71 & 39 & 106 & 110 \\
\hline 123 & $765 \mathrm{C}$ & 60 & $\mathrm{R}$ & 5 & 061.064 & 87136 & $\mathrm{rd} / \mathrm{gn}$ & $<20$ & & 439 & 41 & 16 & 16 & 136 & 12 & 26 & 116 & 16 & 2291 & 20 & 183 & 324 \\
\hline 123 & $765 \mathrm{C}$ & 60 & R & 5 & $116-119$ & 87137 & gry-gn & $<2$ & & 258 & 47 & 100 & 20 & 142 & 29 & 20 & 63 & $<1$ & 323 & 11 & 196 & 115 \\
\hline 123 & $765 \mathrm{C}$ & 60 & A & 5 & 116-119 & 88897 & only it gn & & & 511 & 41 & 75 & 13 & 230 & 221 & 15 & 128 & $<1$ & 985 & $<5$ & 189 & 145 \\
\hline 123 & $765 \mathrm{C}$ & 60 & $\mathrm{R}$ & 5 & $120-123$ & 87138 & & $<20$ & & 53 & $<35$ & $<7$ & 12 & 143 & 33 & $<5$ & 116 & $<1$ & 423 & $<5$ & 165 & 97 \\
\hline 123 & $765 \mathrm{C}$ & 61 & R & 1 & 033.036 & 87141 & b-rd & & & 3093 & 155 & 82 & 22 & 77 & 50 & 90 & 127 & 14 & 56 & 29 & 99 & 150 \\
\hline 123 & $765 \mathrm{C}$ & 61 & R & 1 & $050-052$ & 88898 & red bn>>lt gn & & & 890 & 184 & 71 & 26 & 72 & 35 & 57 & 117 & 23 & 40 & 52 & 166 & 268 \\
\hline 123 & $765 \mathrm{C}$ & 61 & R & 1 & $061-064$ & 87139 & & & & 384 & 51 & 40 & 12 & 143 & 25 & 14 & 107 & 21 & 108 & 16 & 160 & 190 \\
\hline 123 & $765 \mathrm{C}$ & 61 & R & 1 & 061.064 & 87140 & It. gry \& rd & $<2$ & & 96 & $<35$ & 35 & 24 & 83 & 14 & 9 & 54 & 24 & 104 & 9 & 210 & 184 \\
\hline 123 & $765 \mathrm{C}$ & 61 & $R$ & 2 & 052.056 & 88899 & only red bn & & & 326 & 70 & 75 & 20 & 67 & 45 & 58 & 75 & 18 & 60 & 22 & 95 & 158 \\
\hline 123 & $765 \mathrm{C}$ & 61 & R & 4 & 071.074 & 88228 & & & & 468 & 602 & 19 & 51 & 97 & 24 & 53 & 124 & 21 & 106 & 86 & 153 & 395 \\
\hline 123 & $765 \mathrm{C}$ & 61 & R & 4 & 079-082 & 87143 & rd & & & 90 & 123 & 21 & 65 & 111 & 39 & 39 & 112 & 16 & 33 & 50 & 183 & 479 \\
\hline 123 & $765 \mathrm{C}$ & 61 & R & 4 & 079.082 & 87144 & gry & & & 68 & 89 & 23 & 63 & 196 & 39 & 37 & 111 & 21 & 450 & 52 & 260 & 546 \\
\hline 123 & $765 \mathrm{C}$ & 61 & $\mathrm{R}$ & 4 & 079.082 & 87148 & gn & $<20$ & & 85 & 129 & 17 & 67 & 220 & 19 & 36 & 114 & 25 & 571 & 46 & 290 & 528 \\
\hline 123 & $765 \mathrm{C}$ & 61 & R & 4 & 079.082 & 87149 & rd & $<20$ & & 149 & 86 & 17 & 68 & 101 & 24 & 38 & 102 & 19 & 32 & 42 & 202 & 420 \\
\hline
\end{tabular}




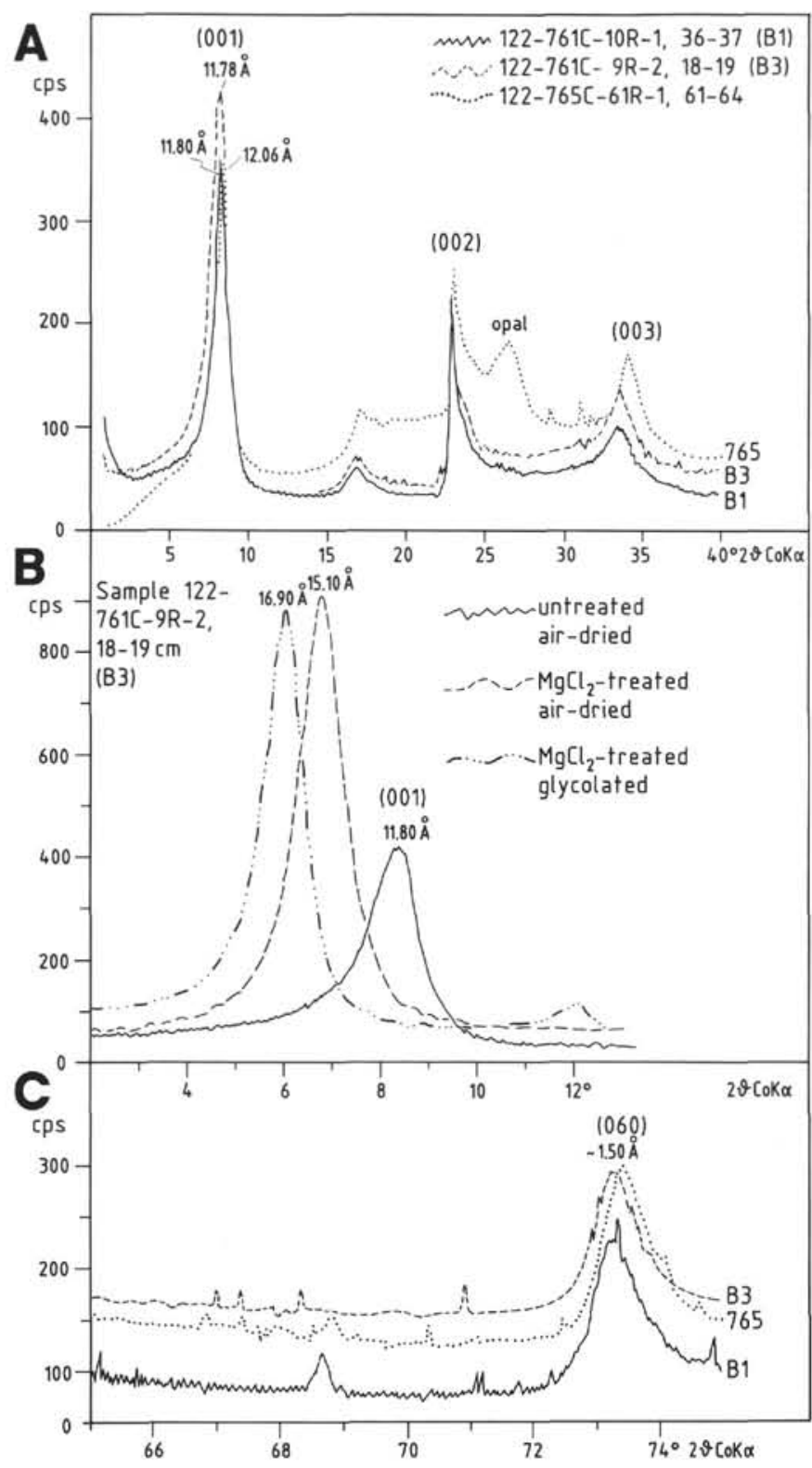

Figure 4. A. X-ray diffractograms of three untreated bentonite samples. Intensity in counts per second (cps). Note that the base reflex (001) is almost identical for all three samples. B. (001) baseline of smectite of Sample 122-761C-9R-2, 18-19 cm, for different sample preparations. C. (060) reflexes of smectite for the same samples (and with same symbols) as in (A).

with the Haycock Marl of the Muderong Shale (Valanginian to Aptian) in the Dampier Basin, a partly restricted, low-energy offshore marine deposit of the Carnarvon Basin (Hocking et al., 1987). The porcellanite horizons might partly be equivalents of the Windalia Radiolarite, although no Aptian age was established at Site 761 .

3. Above about 234 mbsf eupelagic nannofossil chalks, deposited in a water depth of more than about $1000 \mathrm{~m}$, were recovered ("mature ocean phase").

The biostratigraphic age of this section (Site 761, about $240-260 \mathrm{mbsf}$ ) is poorly constrained. Unambiguous nannofossil age determinations are from Section 122-761C-7R-1, 100 $\mathrm{cm}$ ("late Berriasian-early Valanginian," Bralower and
Siesser, this volume) and from Sample 122-761C-7R-1, 31-34 $\mathrm{cm}$ (Calcicalathina oblongata Zone CC3, late Valanginian; P. Čepek, pers. comm., 1990). All samples from Cores 122$761 \mathrm{C}-8 \mathrm{R},-9 \mathrm{R}$, and $-10 \mathrm{R}$ are "late Kimmeridgian to late Valanginian" in age (P. Čepek, pers. comm., 1990). The belemnites from Core 122-761B-30X belong to the genus Belemnopsis cf. jonkeri Stolley (1929), which Mutterlose (in press) assigns to a Berriasian to early Valanginian age by correlation with established palynomorph ages from belemnite-bearing sediments at Site 763 (Brenner, this volume, chapter 31). However, according to Challinor (1989) Belemnopsis $\mathrm{cf}$. jonkeri Stolley ranges from late Tithonian to Neocomian age; therefore, a Tithonian age cannot be excluded for the belemnite horizon at Site 761 .

Tentatively, we assume a (Tithonian to) Berriasian age for the basal (belemnite) sand (257-262 mbsf), and a late Berriasian to late Valanginian age for the section between 240 and 257 mbsf containing the bentonites B1-B6. This section is obviously very condensed and might contain a number of hidden smaller hiatuses, although phosphatic or manganese horizons were not observed. At 240 mbsf we assume a major ( $>20 \mathrm{Ma}$ ) hiatus because (upper Aptian-) Albian (Section 122-761C-6R-CC) directly overlies Valanginian strata (Section 122-761C-7R-1). The same hiatus was also observed in Site 762 (Brenner, this volume, chapter 31 ).

\section{Site 763}

At Site 763 on the southwestern Exmouth Plateau, we discovered bentonitic claystones only in Samples $122-763 \mathrm{C}$ 29R-4, 102-104 cm (870 mbsf), and 122-763B-26R-4, 28-30 cm ( 842 mbsf). Site 763 penetrated a $414-m$-thick "syn-rift" section of shelf-margin prodelta origin (Haq, von Rad, O'Connell, et al., 1990). Sample $122-763 \mathrm{C}-29 \mathrm{R}-4,102-104 \mathrm{~cm}$, is from a $7-\mathrm{cm}$-thick, dark bluish gray $(5 \mathrm{~B} 4 / 1)$ bentonite layer in a section of very dark gray, middle to upper Berriasian silty claystone. Sample $122-763 \mathrm{C}-26 \mathrm{R}-4,128-131 \mathrm{~cm}$, is a montmorillonitic claystone layer, also intercalated in a very dark gray, silty claystone sequence of middle to late Berriasian age.

\section{Site 765}

Site 765 in the Argo Abyssal Plain (Fig. 1) penetrated Berriasian to Valanginian pelagic claystones deposited at or just below the calcite compensation depth (CCD) $(>2600 \mathrm{~m}$ paleo-water depth). These sediments (Cores 123-765C-58R to $-62 \mathrm{R})$ are interbedded with a great variety of "bentonitic claystones" (see section on Argo Abyssal Plain bentonites) overlying oceanic crust (see Thurow and von Rad, in press). Overlying these claystones, in Cores $123-765 \mathrm{C}-56 \mathrm{R}$ to $-58 \mathrm{R}$, calcisphere-rich turbidites were penetrated which might be correlated with the hemipelagic calcisphere chalks of Site 761 (see above).

\section{Site 261}

DSDP Site 261 is also located in the Argo Abyssal Plain (Fig. 1) and penetrated upper Kimmeridgian to Neocomian sediments overlying oceanic crust. Bentonitic claystones, interbedded with dark-brown (sub-CCD) claystone, can be inferred from very high montmorillonite contents (according to XRD analysis) and the waxy, "soapy" appearance in Samples 261-29-2, 25-33 cm, and 40-43 (light-gray layer, Valanginian), and 261-31-4, 50-55 cm (white layer, Berriasian to Valanginian; Veevers, Heirtzler et al., 1974; J. Dumoulin, pers. comm., 1990).

\section{Site 766}

Site 766 is located in the easternmost Gascoyne Abyssal Plain at the base of the steep western escarpment of the 
Exmouth Plateau (Figs. 1 and 2). The oldest, uppermost Valanginian sandstones and siltstones were probably deposited at a paleo-water depth of about $1000 \mathrm{~m}$ and contain redeposited shallow-water terrigenous or shelf material mixed with volcaniclastic debris. These sediments are interbedded with thin, impure bentonitic claystones.

\section{Carnarvon Basin}

In the Carnarvon Basin (southwest of the Exmouth Plateau) Hocking et al. (1987) mention bentonitic sequences (tuffs, etc.) intercalated in the argillaceous siltstones of the Muderong Shale (Valanginian to Aptian) and of the Gearle Siltstone (Albian to Turonian). The latter occurrence is clearly younger than the bentonites discussed here, while the former might have the same age.

\section{SEDIMENTARY FABRIC AND FACIES ASSOCIATION OF BENTONITE LAYERS}

\section{Wombat Plateau Bentonites}

Color, fabric, and facies association of the six lower Neocomian bentonite layers (B1-B6), penetrated at Site 761, are shown in Plate 1 and Figure 3. The bentonites are subdivided by fabric and composition into two distinctive groups:

1. White, pink, and light gray, pure smectite bentonites (B1, B3, B5) with a "waxy" appearance, usually grading upward into slightly darker colors (light gray, pale yellow) with distinct lower and gradational upper contacts; and

2. (Dark) gray to brown, impure silty bentonitic claystones (B2, B4).

The oldest and lowermost bentonite (B1) is about $0.5 \mathrm{~m}$ thick (thickness from log interpretation), of which $24 \mathrm{~cm}$ were recovered in Core 122-761C-10R (Pl. 1, Fig. 1). The bentonite is completely homogeneous and pink (5YR7/4) at its base, a pure smectite bentonite. In its middle part there are darkercolored bands; toward the top it is mottled by bioturbation with light brownish gray (10YR6/2) color. The composition is that of an impure bentonite.

B2 is a 0.1 -m-thick, brown (7.5YR5/4), silty, bentonitic claystone with a very heterogeneous composition (Pl. 1, Fig. 2).

B3 is a 0.2 -m-thick, white (10YR8/3), pure bentonite, which is distinctly mottled throughout and grades upward into a pale yellow (2.5Y7/4) claystone (PI. 1, Fig. 3). The upper contact is gradational with the overlying pale olive calcisphere chalk.

B4 is a $0.2-\mathrm{m}$-thick, very dark gray (base, $2.5 \mathrm{Y} 3 / 0$ ) to gray (top, 2.5Y5/6), heterogeneous bentonitic sandy claystone, which is thoroughly mottled by tiny fucoid-type burrows and filled with the over- and underlying pale yellow (2.5Y7/4) calcisphere nannofossil chalk. Although the upper contact is comparatively distinct, the color grading suggests a rapid (?turbiditic) event (Pl. 1, Fig. 4).

B5 is a 0.7 -m-thick, extremely white $(5 \mathrm{Y} 8 / 0)$, more or less homogeneous, pure smectite bentonite, of which $35 \mathrm{~cm}$ were recovered in Section 122-761C-8R-1 (Pl. 1, Fig. 5) and about $20 \mathrm{~cm}$ in Core 122-761B-29X (Pl. 1, Fig. 6). Although the lowermost part of the bentonite appears to be missing, a distinct lower contact is evident. Upward, B5 grades into light gray to brown colors with increasing bioturbation, with mottles of the overlying pale olive (2.5Y $7 / 4)$ to light olive-brown (2.5Y5/4) calcisphere nannofossil chalk to marl.

B6 is a $0.5-\mathrm{m}$-thick, very pale brown bentonite, of which about $30 \mathrm{~cm}$ were recovered in Core $122-761 \mathrm{C}-7 \mathrm{R}$ (Pl. 2). This bentonite shows a sharp lower contact and a very gradual transition to the overlying, bioturbated, light yellowish brown (10YR6/4) calcisphere nannofossil chalk. Whereas the top part of this layer is slightly mottled, the lower part of this bentonite is distinctly parallel- (to ?cross-) laminated with millimeterthick bands of pale yellow (2.5Y7/4) and pink (5YR7/3) color. This clearly suggests an origin as ash turbidite (see below).

The uppermost clay layer, which is characterized by a distinct low-velocity interval and natural gamma-ray maximum (Fig. 3), is a brown silty claystone to marlstone, of which about $30 \mathrm{~cm}$ were recovered in Core 122-761C-6R (Albian).

\section{Argo Abyssal Plain Bentonites}

At Site 765 we distinguish several types of smectitedominated "bentonitic claystones" (see also Thurow and von $\mathrm{Rad}$, in press). They are intercalated with pelagic (calcareous) silty claystones, which locally contain radiolarians or redeposited calcareous shell fragments. All distinct bentonite layers in Cores $123-765 \mathrm{C}-59 \mathrm{R}$ to $-62 \mathrm{R}$ are of late Berriasian to Valanginian age, those in Cores $123-765 \mathrm{C}-57 \mathrm{R}$ and $-58 \mathrm{R}$ are of Valanginian age. A varicolored, waxy interval of smectitic claystone interval in Section 123-765C-59R-4, 125-150 cm, is comparable to a similar "bentonitic" interval 261-29-2, 25-50 $\mathrm{cm}$, described from DSDP Site 261 (see below). The following four "bentonite types" were distinguished based on visual appearance:

Type 1: Whitish/light gray to light greenish gray smectite claystone of "soapy" or "waxy" appearance. The 5- to 14-cm-thick layers have distinct lower and gradual upper contacts indicating a redeposited (?distal ash turbidite) rather than a air-fall ash origin (Sections 123-765C-60R-5, 112-125 $\mathrm{cm}$; $123-765 \mathrm{C}-61 \mathrm{R}-1,58-63 \mathrm{~cm}$; and $123-765 \mathrm{C}-61 \mathrm{R}-4,77-91$ $\mathrm{cm})$. The bentonites contain small percentages of opaline material (Fig. 4A).

Type 2: Greenish gray smectitic claystone of "soapy" or "waxy" appearance. The layers are up to $3 \mathrm{~cm}$ thick and have distinct upper and lower contacts. They might represent altered in-situ air-fall ash layers (Sections 123-765C-61R-1, 89-92 cm; 123-765C-61R-1, 99-101 cm; 123-765C-61R-1, $115-118 \mathrm{~cm}$; and $123-765 \mathrm{C}-62 \mathrm{R}-1,58-61 \mathrm{~cm}$ )

Type 3: A whitish or gray-green smectite claystone similar to type 1 but has a slightly mottled appearance and lacks sharp contacts (Samples 123-765C-60R-5, 58-64 cm; 123-765C$61 \mathrm{R}-1,0-8 \mathrm{~cm}$; and $123-765 \mathrm{C}-61 \mathrm{R}-3,15-22 \mathrm{~cm})$. They might be type 1 bentonites the original structure of which was destroyed by either bioturbation of diagenetic discoloration.

Type 4: Intensely brick-red to dark-red smectite-rich claystones with soapy or waxy appearance and diffuse upper and lower contacts that include all doubtful bentonites (e.g., Sections 123-765C-57R-7, 7-10 cm, and 123-765C-58R-2, 136$137 \mathrm{~cm})$.

\section{Gascoyne Abyssal Plain Bentonites}

Site 766, located at the foot of the southwestern Exmouth Plateau, contains bioclastic-volcaniclastic turbidites in its oldest (uppermost Valanginian) sediment section. Thin, "waxy," smectite-rich clay laminae in the upper part of the section (Cores 123-766A-45R to $-48 R$ ) are somewhat similar to the bentonitic claystones of Site 765 , although they are very impure and mixed with abundant fine-grained detrital material.

\section{Southern Central Exmouth Plateau}

Sites 762 and 763 (Fig. 1) terminated in upper Berriasian silty prodelta claystones which are time-equivalents of the Barrow Group of the adjacent Northwest Shelf (Barber, 1982; Bradshaw et al., 1988). The Barrow Group was deposited as an up-to-1.5-km-thick, northward prograding clastic slope/ 
margin wedge (Boote and Kirk, 1989; Boyd and Bent, this volume) shed from the southern transform margin (Figs. 2 and $6)$. The prodelta mudstones were deposited at high sedimentation rates. Montmorillonitic claystone layers with bluish gray colors were observed at two intervals in Site 763 in the middle to upper Berriasian section. Other potential "impure bentonites" at Sites 762 and 763 might have escaped our attention.

\section{COMPOSITION AND ULTRASTRUCTURE OF BENTONITIC LAYERS}

\section{Mineralogical Composition}

\section{Wombat Plateau Bentonites}

The Wombat Plateau bentonites can be classified in two major groups, pure smectite bentonite and impure bentonitic claystones (see above).

1. Pure (white to pink) smectite bentonites (B1 base, B3, and B5 base) are characterized by a very homogeneous, cryptocrystalline matrix of pure montmorillonite $(>95 \%$, sometimes $>99 \%$ ) that shows a typical pinpoint extinction under crossed nicols (Pl. 3, Fig. 1). XRD analysis proves that the rocks are essentially carbonate-free and contain extremely well-ordered, mainly dioctahedral $12 \AA$-Na-smectite (R. Petschick, pers. comm., 1990) as the only clay mineral. Figure 4A shows diffractograms of untreated airdried samples with the well-developed (001), (002), and (003) base reflexes of smectites. If treated by $\mathrm{MgCl}_{2}$ solution, the (001) peak of the air-dried samples is displaced to $15 \AA$; if treated by $\mathrm{MgCl}_{2}$ solution and glycolated, the basal reflex moves to $17 \AA$ (Fig. $4 \mathrm{~B})$. The $(060)$ reflexes of the bentonites were determined to be around $1.5 \AA$ (Fig. $4 \mathrm{C}$ ). According to the $(001)$ and $(060)$ reflexes, the $12 \AA$-smectite is a dioctahedral, $\mathrm{Al}^{3+}$-rich smectite with the approximate chemical composition of $\mathrm{Na}_{0.33}(\mathrm{Al}, \mathrm{Mg})_{2} \mathrm{Si}_{4} \mathrm{O}_{10}(\mathrm{OH})_{2} \cdot \mathrm{nH}_{2} \mathrm{O}$ (R. Petschick, pers. comm., 1990).

A "vitroclastic fabric" is produced by small $(10-20 \mu \mathrm{m})$, flat, partly V-shaped glass shards that have been replaced by smectite (Pl. 4, Figs. 1, 3). SEM photomicrographs show the typical "honeycomb texture" of smectite blades, partly in spherical aggregates of about $5-\mu \mathrm{m}$ diameter with a very regular, open honeycomb texture (Konta, 1986) (PI. 4, Fig. 2). Almost all intraclasts are overgrown or replaced by smectite. Exceptions are a few terrigenous quartz crystals $(2-10 \mu \mathrm{m})$ and feldspar (plagioclase) grains, and trace amounts of clinoptilolite, "glauconite-type" phyllosilicates, and calcispheres. Bentonite B3 also contains traces of sanidine and altered bubble-wall glass shards. Heavy minerals are dominated by apatite and zircon.

Chemically, the pure smectite bentonites approach the average composition of smectite (Table 2). If calculated for LOI-free (loss on ignition)-that is, mainly $\mathrm{H}_{2} \mathrm{O}$-free-substance, the average of the three purest samples (B1 base, B3, and $\mathrm{B} 5$ base) is $68.5 \% \mathrm{SiO}_{2}, 0.27 \% \mathrm{TiO}_{2}, 19.1 \% \mathrm{Al}_{2} \mathrm{O}_{3}, 3.3 \%$ $\mathrm{Fe}_{2} \mathrm{O}_{3}, 0.5 \% \mathrm{CaO}, 0.64 \% \mathrm{Na}_{2} \mathrm{O}, 0.6 \% \mathrm{~K}_{2} \mathrm{O},<70 \mathrm{ppm} \mathrm{Ba},<40$ ppm Sr, and $<20$ ppm V. The average LOI $\left(\mathrm{H}_{2} \mathrm{O}\right.$ content), calculated in percent of the total sample, is about $17 \%$.

2. Impure (dark gray to brown) silty bentonitic claystones (Pl. 2, Fig. 2) are more heterogeneous than the pure bentonites because the upper parts of pure bentonites (B1 and B5) are mixed with the overlying calcisphere chalk by bioturbation, or because they were originally deposited as more heterogeneous claystone (B2, B4, and Site 763 bentonites). Usually they are siltier or sandier, mottled, and contain smectite as the main clay mineral, in addition to trace amounts of illite. Only the bentonite of Site 763 contains kaolinite as a minor clay mineral component, the typical clay mineral derived from the weathering of plutonic rocks under humid conditions and the dominant clay mineral of the Barrow Group prodelta claystones. The smectite of these claystones is mixed with a great variety of pelagic (biogenic), terrigenous, volcanic, and authigenic components.

Biogenic components consist of calcispheres (often smectite-filled, Pl. 4, Fig. 4), coccoliths, mollusc fragments, sponge spicules, and recrystallized radiolarians.

Of terrigenous origin are silt-sized quartz $(10-50 \mu \mathrm{m})$, feldspar (especially plagioclase), biotite (especially abundant in Site 763, Pl. 3, Fig. 3), garnet (Site 763), tourmaline, titanite, and zircon (rounded varieties).

Of special interest for the origin of these bentonitic claystones are volcaniclastic grains. They include (1) altered, often ferruginized, volcanic rock fragments (B3, PI. 2, Fig. 2); (2) colorless, more or less fresh (Pl. 4, Fig. 7) bubble-wall and cuneiform glass shards (Pl. 3, Figs. 6,9), which may be slightly to completely altered to smectite (Pl. 3, Fig. 5); and (3) euhedral sanidine crystals (Pl. 3, Figs. 5, 6). B3 (and B2) are especially rich in these glass shards. We measured a refractive index of $n=1.485-1.495$ in the freshest-looking shards, which correlates with a highly silicic (rhyolitic) composition with $>70 \% \mathrm{SiO}_{2}$ (Huber and Rinehart, 1966; von Rad and Mühe, 1990). However, the refractive index is probably lowered by the partial hydratization and zeolitization of the glass shards. EDX analysis indicates also a Si- and $\mathrm{K}$-rich, rhyolitic composition (Pl. 4, Fig. 7). Other glass shards were completely replaced by clinoptilolite (Pl. 3, Fig. 4). Other volcanicderived minerals include clinopyroxene (B2) and the apatitezircon-dominated heavy mineral assemblage (B1, B2, B6, and B763).

Apatite (Pl. 3, Fig. 7) and slender, long-prismatic zircon (Pl. 3, Figs. 8, 10) are often interpreted to indicate a volcanic source rock (Zimmerle and Gaida, 1980; Pupin, 1980; Winkler et al., 1985; Samson et al., 1989; Zimmerle, 1989).

Authigenic components include glauconite (displaced from associated hemipelagic sediments), authigenic clinoptilolite (derived from silica diagenesis of volcanic glass and skeletal opal; see Pl. 4, Fig. 4), ?authigenic sanidine, reworked dolomite, and pyrite (diagenesis of organic matter, especially in Site 763).

Geochemically, the impure bentonitic claystones of the Wombat Plateau Site 761 are lower in $\mathrm{SiO}_{2}(56 \%-67 \%$, LOIfree values), higher in $\mathrm{TiO}_{2}(0.3 \%-2.0 \%)$, variable in $\mathrm{Al}_{2} \mathrm{O}_{3}$ $(14.5 \%-26.4 \%)$, variable in $\mathrm{Fe}_{2} \mathrm{O}_{3}(2.6 \%-11.3 \%$, highest values in brown claystones), high in $\mathrm{CaO}(0.7 \%-3.1 \%$, calcispheres, coccoliths), high in $\mathrm{K}_{2} \mathrm{O}(0.8 \%-2.5 \%$, volcanic glass, $\mathrm{K}$-feldspar), and higher in $\mathrm{Ba}, \mathrm{Sr}$, and in $\mathrm{V}$, if compared with the pure bentonites (Tables 2 and 3 ).

\section{Chemical Composition of Leg 122 Bentonites}

Chemical analyses are important to characterize the composition of different bentonites and to attempt to address genetic questions, such as the approximate chemistry of the original magmas producing the volcanic ash (Tables 2 and 3; Winkler et al., 1985). Since bentonites are highly altered ash layers, the second question is very difficult to answer. We used only samples that were essentially carbonate-free and calculated them to $100 \%$ on a LOI-free basis, assuming that most of the about $\sim 17 \%$ LOI is caused by smectite-bound $\mathrm{H}_{2} \mathrm{O}$ and not by other volatiles $\left(\mathrm{CO}_{2}, \mathrm{SO}_{2}\right.$, etc.). This assumption is supported by the fact that XRD, SEM, and optical analyses prove that at least our "pure bentonites" consist essentially only of pure montmorillonite.

Figure $5 \mathrm{~A}$ shows a plot of $\mathrm{SiO}_{2}$ vs. $\mathrm{K}_{2} \mathrm{O} . \mathrm{SiO}_{2}$ is a convenient measure for the differentiation of volcanic glass 

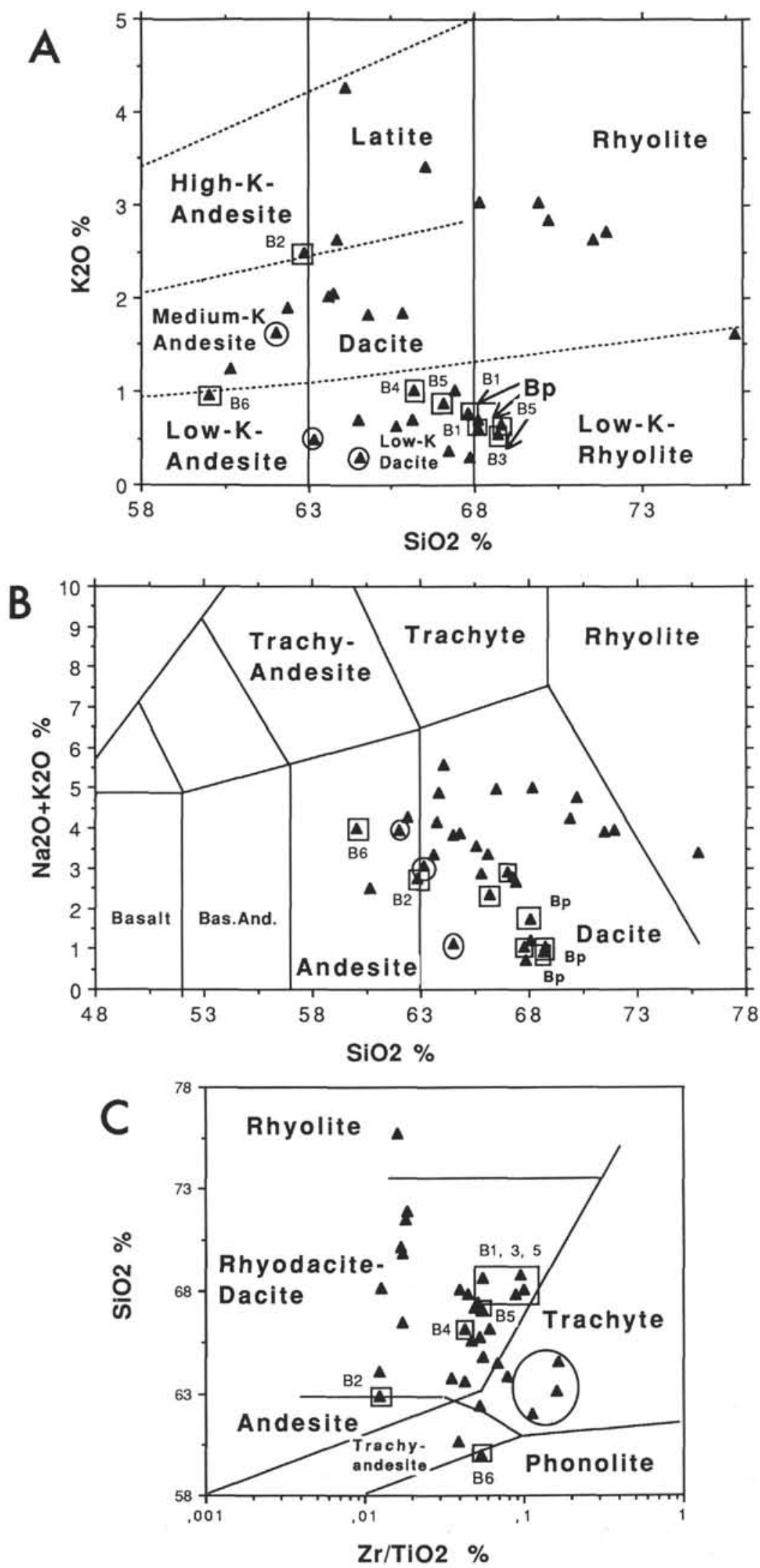

Figure 5. Geochemistry of all analyzed bentonitic clays from Legs 122 and 123 (except Site 763; LOI-free values, see Tables 2 and 3). B1-B6 = bentonite number (see Table 1), $\mathrm{Bp}=$ pure bentonite (Site 761), Site 766 samples are circled, and Site 761 samples are boxed. A. $\mathrm{SiO}_{2}$ vs. $\mathrm{K}_{2} \mathrm{O}$ plot with volcanic rock classification after Peccerillo and Taylor (1976) B. SiO ${ }_{2}$ vs. total alkalies $\left(\mathrm{Na}_{2} \mathrm{O}+\mathrm{K}_{2} \mathrm{O}\right)$ TAS-plot (after Le Bas et al., 1986). C. $\mathrm{SiO}_{2}$ vs. $\mathrm{Zr} / \mathrm{TiO}_{2}$ ratio after Winchester and Floyd (1977). For explanation see text. 
from "andesitic" (57\%-68\%) to "dacitic" $(63 \%-68 \%)$ and "rhyolitic" composition ( $>68 \%)$. In fresh volcanic glass shards $\mathrm{K}_{2} \mathrm{O}$ contents differ very much in tholeiitic and calcalkaline rocks and have a tectonic and petrogenetic meaning (von $\mathrm{Rad}$ and Mühe, 1990). However, $\mathrm{K}_{2} \mathrm{O}$ is also highly sensitive to alteration. If we disregard the very impure bentonites B2 and B6 (which lie in the "andesitic field"), all Site 761 bentonites cluster in the low- $\mathrm{K}\left(<1 \% \mathrm{~K}_{2} \mathrm{O}\right)$ dacite/rhyolite $\left(66 \%-69 \% \mathrm{SiO}_{2}\right)$ field. Site 766 bentonites have a similar composition, whereas Site 765 bentonites represent a wide variety of compositions ranging from medium-K andesite to (low- to high-K) dacite and medium-K rhyolite (Thurow and von $\mathrm{Rad}$, in press). In the total alkali $\left(\mathrm{Na}_{2} \mathrm{O}+\mathrm{K}_{2} \mathrm{O}\right)$ vs. $\mathrm{SiO}_{2}$ plot after Le Bas et al. (1986), all Site 761 bentonites (except B2 and B6) are in the dacitic field (Fig. 5B).

$\mathrm{Ti}$ and $\mathrm{Zr}$ are immobile elements that are very resistant to alteration by weathering or halmyrolysis (Winkler et al., 1985). Therefore we plotted the $\mathrm{Zr} / \mathrm{TiO}_{2}$ ratio vs. $\mathrm{SiO}_{2}$ after Winchester and Floyd (1977). In this diagram most Site 761 bentonites (B1, B3, and B5) plot in the "dacite to rhyodacite" field (Fig. 5C). Only the $\mathrm{TiO}_{2}$-rich bentonites $\mathrm{B} 2$ and $\mathrm{B} 6$ lie in the (trachy)andesitic and andesitic field. Because of the impurity of these bentonites, this has probably no genetic significance.

\section{Diagenetic Alteration of Ash Layers}

The bentonites studied are so strongly argillized that during Leg 122 they were originally not identified as altered ash layers. Shore-based studies then discovered unambiguous evidence for a volcaniclastic origin of these layers from vitric ash. Clearly, these bentonites represent the diagenetically homogenized end products of what were originally vitric ash layers of dacitic to rhyolitic composition. The alteration of silicic glass is a four-step process, involving (1) diffusioncontrolled hydration and alkali exchange, (2) partial to complete dissolution of glass shards, (3) precipitation of montmorillonite, and (4) late-stage precipitation of clinoptilolite and other secondary phases in the remaining pore space. SEM (PI. 3) and thin-section microscopy (Pl. 4) demonstrate the gradual alteration of silicic glass:

1. Fresh or almost fresh glass shards (PI. 3, Figs. 5, 7) are very rare. Since the refractive index is slightly lowered $(n=$ 1.490), we cannot exclude a slight initial alteration (hydratization, ion exchange).

2. Slightly altered glass shards show an etched surface with small corrosion pits with incipient smectite (or clinoptilolite) authigenesis.

3. Moderately altered (smectitized) glass shards with flat, V-shaped, cuneiform, or bubble-wall (vesicular) shard shapes remain intact (the glass matrix is, however, partly or completely dissolved) and montmorillonite-with the typical honeycomb structure-was reprecipitated in its place. We also observed partly (Pl. 3, Figs. 3, 5) or completely zeolitized glass shards (Pl. 3, Fig. 4), especially in bentonite B3.

4. Completely smectitized bentonites (Pl. 4, Fig. 2) show no vestiges of the original shape of glass shards. These bentonites commonly show that even plagioclase, K-feldspars, and other crystals are either overgrown by a dense network of montmorillonite or totally replaced by smectite.

Zeolites are a rare constituent of the bentonites investigated. Clinoptilolite is much more common than ?phillipsite (only in B3, which might be an altered hyaloclastite). Euhedral clinoptilolite either replaces glass shards (see above) or it forms the latest cavity-filling phase in calcispheres and other open pores. It clearly postdates smectite, which is partially replaced by the zeolite crystals. Because clinoptilolite is also very common in the calcisphere nannofossil chalks and marls, which are full of opaline skeletons (radiolarians and sponge spicules recrystallized to opal-CT), part of the clinoptilolite in the bentonites might have been derived from the dissolution of skeletal opal, and not from dissolved silicic glass as parent material (Riech and von Rad, 1979). Phillipsite could also have been originally precipitated from volcanic sources and then been altered to clinoptilolite during late diagenesis. Kastner and Stonecipher (1978) have shown that in pre-Late Cretaceous, carbonate-rich, oceanic sediments clinoptilolite is by far the dominant zeolite, apparently also replacing previously formed phillipsite.

\section{DISCUSSION}

\section{Plate Tectonic and Paleogeographic Setting (Latest Jurassic to Neocomian)}

During early Mesozoic times, the northwest Australian passive continental margin was part of the eastern Gondwanan continent facing the southern Tethys sea (von Rad et al., 1989; Ludden, Gradstein, et al., 1990). During the Middle to Late Jurassic large parts of the Wombat Plateau and Exmouth Plateau were uplifted above sea level and became an area of erosion or nondeposition. In the Tithonian to Berriasian interval, continental breakup between Gondwana (northern Exmouth Plateau) and its hypothetical conjugate margin, the "Argo Landmass," was followed by seafloor spreading and rapid subsidence of the Argo Abyssal Plain (Fig. 2). This "birth" of a narrow, east-west-trending proto-Indian Ocean was documented by the deposition of a peculiar suite of hemipelagic "juvenile-ocean sediments" of Neocomian age. Rapid subsidence and the third-order sea-level rise (cycles 2.1 and 2.2 ; 128.5-121.5 Ma; Haq et al., 1987) caused a rapid relative sea-level rise, especially at the outer continental margin of the northern Exmouth Plateau. On the Wombat Plateau the juvenile-ocean sediments consist of a transgressive series of condensed, littoral to nearshore sands and shelfal belemnite-bearing sandy silts, followed by hemipelagic calcisphere nannofossil chalks alternating with thick bentonite layers (Fig. 3). According to Bralower (this volume), heavy ${ }^{18} \mathrm{O}$ values suggest a comparatively deep, cool habitat for the belemnites or strong vital effects. Restricted circulation and an unstable "juvenile ocean" paleoenvironment are inferred from the opportunistic, low-diversity assemblage of belemnites, calcispheres, and thoracospheres (Bralower, this volume).

On the Argo Abyssal Plain, pelagic, reddish to greenish claystones and radiolarian claystones with thin bentonite intercalations were deposited at a water depth of about 2.5-3 $\mathrm{km}$. The final separation of Greater India and Australia, which created the Gascoyne and Cuvier abyssal plains, started 10-20 $\mathrm{Ma}$ after the breakup of Argo Abyssal Plain, during late Valanginian (magnetic Chron M10) time (Veevers, Heirtzler, et al., 1974; Fullerton et al., 1989). The breakup event is constrained by magnetic anomalies, the oldest sediments overlying ?oceanic crust at Site 766 (late Valanginian; Ludden, Gradstein, et al., 1990), and by the breakup unconformity in Sites 762 and 763 separating the pre-breakup clastic wedge of the "Barrow Group" (Berriasian to Valanginian) and a transgressive Hauterivian to Aptian organic-rich claystone series (Boyd and Bent, this volume; see Fig. 2).

The investigated bentonite layers are all of late Berriasian to Valanginian age. However, they were recovered from five distinctly different sedimentary and tectonic settings (Figs. 2 and 6): 
1. Distal prodelta claystone of the "Barrow Group" clastic margin wedge (Fig. 2A; Site 763, paleo-water depth about 100-200 m, comparatively high sedimentation rate).

2. Glauconitic and volcaniclastic sandstone and siltstone (latest Valanginian) interbedded with inclined basaltic sills in the easternmost Gascoyne Abyssal Plain, at the western foot of the Exmouth Plateau (Fig. 2B; Site 766, paleo-water depth $800-1000 \mathrm{~m}$, high sedimentation rates, no connection to Barrow delta).

3. Condensed, hemipelagic calcisphere nannofossil chalk and marl, deposited on the rapidly subsiding, tilted block of the Wombat Plateau (Fig. 2A), part of which was probably still an emergent island (Site 761, paleo-water depth rapidly increasing from $<100 \mathrm{~m}$ to several hundred meters, sedimentation only $3 \mathrm{~m} / \mathrm{m} . \mathrm{y}$.).

4. Pelagic, reddish brown and greenish claystones and radiolarian silty claystone with carbonate turbidites in the southernmost Argo Abyssal Plain (Fig. 2A, Site 765, paleowater depth $>3500 \mathrm{~m}$ ?, sub-CCD, very low sedimentation rates).

5. Pelagic reddish brown claystones in the central Argo Abyssal Plain (Site 261, paleo-water depth $>3000 \mathrm{~m}$ ?, sub$\mathrm{CCD}$, very low sedimentation rates).

In addition to these very different environments, bentonitic clays were recorded from the Muderong Shale (Valanginian to Aptian) in the Carnarvon Basin (Fig. 2A), south of the Exmouth Plateau (Hocking et al., 1987). These silty shales were deposited in a low-energy, restricted marine environment during the Valanginian to Aptian, somewhat similar to the Hauterivian to Aptian sediments deposited on top of the Barrow Group equivalent series at Sites 762 and 763 .

\section{Post-Breakup Volcanism Off Northwest Australia}

Normal faulting in the extensional regime of the northwest Australian passive margin started in the late Permian to Triassic with a climax during the Early to Middle Jurassic. Reactivation of these northeast-southwest-trending faults continued during the Jurassic to early Neocomian, when eastwest-trending faults were created and seafloor spreading started in the Argo Abyssal Plain. During this time Greater India was elevated south of the Cape Range Fracture Zone causing the northward progradation of major fluviodeltaic lobes of the Barrow Group toward the central Exmouth Plateau (Fig. 2A).

On the Exmouth Plateau (Site 763), Wombat Plateau (Site 761), and in the adjacent Argo Abyssal Plain (Sites 261 and 765) and Gascoyne Abyssal Plain (Site 766) we discovered the altered ash layers, which shed some light on the important volcanic events associated with the earliest stages of opening of the Indian Ocean during the early Neocomian.

Considerably enhanced igneous activity can be expected if the asthenosphere under the Exmouth Plateau was comparatively hot and the overlying lithosphere stretched and thinned during rifting and after the onset of oceanic spreading (White, 1989). Apparently, volcanic activity was not only associated with Late Triassic to Liassic syn-rift block-faulting events of the northern Exmouth Plateau (von Rad and Exon, 1983; von Rad et al., in press), but also with the continental breakup and the following rapid subsidence at the continent/ocean boundary during the latest Jurassic to Neocomian. This was a surprising discovery, since no direct evidence of Mesozoic volcanic activity was reported from the on- and offshore parts of the Canning Basin (Towner and Gibson, 1983), or the Carnarvon Basin (Hocking et al., 1987). Leg 121 discovered a very thick section of ashes and tuffs in post-breakup sediments of middle-Late Cretaceous age (Peirce, Weissel, et al.,
1989). For northwest Europe, a similar syn-breakup volcanic activity was reported for the Early Cretaceous ("Wealden") (Zimmerle, 1989). The same volcanic event was observed in the Tethys Himalayas (Thakkhola, central Nepal; Gradstein et al., 1989); this area represented the northward-facing continental margin of Greater India, which prior to continental breakup was adjacent to (i.e., south of) the Exmouth Plateau.

If we look for the potential volcanic source areas of our bentonites off northwest Australia during the Early Cretaceous, we have to consider the following areas shown in Figures 2 and 6:

1. Wombat Plateau (Fig. 2A): There is only indirect evidence for volcanic activity on the emergent part of the Wombat Plateau or its vicinity during the early Neocomian. The bentonite layers are very thick (up to $0.7 \mathrm{~m}$ ) with a cumulative thickness of at least $2.2 \mathrm{~m}$. Therefore, we assume a nearby chain of subaerial explosive volcanoes.

2. Joey Rise and Roo Rise (north of Joey Rise) are two large, separate but adjacent, deeply submerged plateaus (together about $30,000 \mathrm{~km}^{2}$ ) at the northwestern projection of the Exmouth Plateau. The rises have a water depth between 2500 and $4000 \mathrm{~m}$ and are probably not underlain by continental, but oceanic or "mixed" crust (Figs. 2A, 2B, and 6). Veevers and Cotterill (1978) suggested that these plateaus were formed as abnormally thick volcanic upgrowth ("epilith") during or after the breakup of the Argo Abyssal Plain. This interpretation is supported by hyaloclastites and basalts cored at the northeastern slopes of both rises which are however undated (Cook et al., 1978). Although these volcanic rocks could not be dated, the outcrops below or near the seismically detected "breakup unconformity" suggest that submarine basaltic volcanism was active during the latest Jurassic to Neocomian (Fig. 2A). Possibly, the volcanic growth of the Joey/Roo epilith coincides with the injection of the dykes into the upper Valanginian sediments of Site 766 . We cannot exclude the possibility that during this time part of the Joey Rise was above sea level and supplied windborne ash material to the Argo Abyssal Plain and Wombat Plateau.

3. Scott Plateau/Oates Canyon: Middle to Late Jurassic volcanism is well known from the vicinity of Scott Plateau (Scott Reef No. 1 well), located northeast of the Exmouth Plateau and east of the Argo Abyssal Plain (Fig. 2A, "OC'). Valdivia dredged a wide variety of volcanic and volcaniclastic rocks from Oates Canyon at the western plateau margin (Hinz et al., 1978). The least weathered of these volcanic rocks are differentiated alkali basalts with a whole-rock $\mathrm{K} / \mathrm{Ar}$ age of 128-132 Ma (i.e., early Neocomian, von Rad and Exon, 1983). This age fits very well with the Berriasian age of the oldest sediments overlying oceanic basalt at Site 765 and suggests that the Scott Plateau volcanism is coeval with the earliest stages of opening of the Argo Abyssal Plain.

4. Wallaby Plateau is a large submarine plateau south of the Exmouth Plateau, which Veevers and Cotterill (1978) also interpreted as a huge volcanic "epilith" (an area of $30,000 \mathrm{~km}^{2}$ by about $1-\mathrm{km}$ thickness = about $30,000 \mathrm{~km}^{3}$ volume; Fig. 2C). A brief but spectacular volcanic event apparently followed the late Neocomian breakup between Australia and "Greater India" and the start of seafloor spreading in the Gascoyne and Cuvier abyssal plains. The Wallaby Plateau experienced an origin similar to that of Iceland, but with an abrupt cessation of volcanism, and subsidence below sea level after the spreading ridge of Cuvier Abyssal Plain jumped to its new position farther northwest (von Rad and Exon, 1983). The age of the tholeiitic basalts dredged from Wallaby Plateau and those sampled on the associated Sonne Ridge (Cuvier Abyssal Plain) is not well constrained ( $\mathrm{K} / \mathrm{Ar}$ age "older than Turo- 
nian"). Based on magnetic anomalies, we assume a Hauterivian to Aptian age.

Seismic reflection profiles across the southernmost Exmouth Plateau near the Cape Range Fracture Zone suggest volcanic intrusions which are probably associated with the westward motion of "Greater India" along the Exmouth Plateau's southern transform margin at about the late Valanginian (Fig. 2A, no. 2; R. Boyd, pers. comm., 1990).

If we assume that the ashes were distributed northwestward by high-altitude eastern trade winds (similar as the present wind circulation), we can speculate that the ash layers of the Argo Abyssal Plain were derived from volcanoes near the Scott Plateau and/or Wombat Plateau/northern Exmouth Plateau and the Wombat Plateau ashes from a nearby source (?Wombat Plateau). The southern Exmouth Plateau and Gascoyne Abyssal Plain ash layers were probably derived from volcanoes located to the south and southeast of these areas (Fig. 6). The explosive volcanism produced ash of a highly differentiated (dacitic to rhyolitic) composition.

\section{Dispersal and Mode of Deposition of Ash Layers}

Ash layers mark short-lived geological events and therefore represent ideal stratigraphic marker horizons if they can be correlated between closely spaced sites (see von Rad and Mühe, 1990). Unfortunately, the Wombat Plateau and Argo Abyssal Plain sites are too far apart and belong to paleobathymetric and paleotectonic settings too different to be lithostratigraphically correlated (Fig. 6). The same holds true for the southern Exmouth Plateau Site 763 and the eastern Gascoyne Abyssal Plain Site 766. Therefore, we have to restrict this discussion to a consideration of the estimated volume and deposition/redeposition mechanisms of the ashes within the four areas represented by Sites 765, 761, 763, and 766 (Fig. 6).
Widespread submarine ash layers are usually derived from explosive subaerial volcanoes or chains of volcanoes, distributing vitreous ash of dacitic to rhyolitic composition via upper troposphere winds (Fisher and Schmincke, 1984). In marginal basins behind island arc volcanoes, such as the PlioceneQuaternary Lau Basin, we observed (1) finely dispersed ash (up to $10 \%$ silt-sized volcanic glass mixed with hemipelagic sediments), (2) distinct air-fall ash layers up to $15 \mathrm{~cm}$ thick, consisting mostly of glass with a downwind decrease of the crystal/glass ratio, usually lacking laminations and grading, and (3) thick, laminated and graded, poorly sorted ash turbidites with distinct lower and indistinct upper boundaries (von Rad and Mühe, 1990).

Because of the strong alteration of the glass into smectite, it is unlikely that finely dispersed ash could be discovered in the Neocomian sediments. The following criteria indicate that the Wombat Plateau bentonites were rapidly deposited as proximal ash turbidites: (1) their great thickness $(10-70 \mathrm{~cm})$, encompassing about $10 \%$ of the total Neocomian sediment thickness at Site 761 (Fig. 3), (2) the distinct lower contacts with the underlying calcisphere nannofossil chalks (Pls. 1 and 2 ) and the (generally) diffuse upper boundaries of the bentonites, disturbed by downcore bioturbation from above (upward transition into the hemipelagic chalk), and (3) the faint lamination to even indistinct cross-lamination in some bentonites (especially B6, Pl. 2). If we postulate that most of the Wombat Plateau bentonites B1 to B6 are ash turbidites, we have to assume that in-situ air-fall ash layers were deposited originally on the shelf and then redeposited by turbidity currents or storm-induced currents into an outer shelf basin or upper slope environment. Similar very voluminous in-situ ashes and ash turbidites were discovered in early post-rift sediments of Late Cretaceous age at Broken Ridge (Peirce, Weissel, et al., 1989).

\section{LATE BERRIASIAN -}

\section{VALANGINIAN}

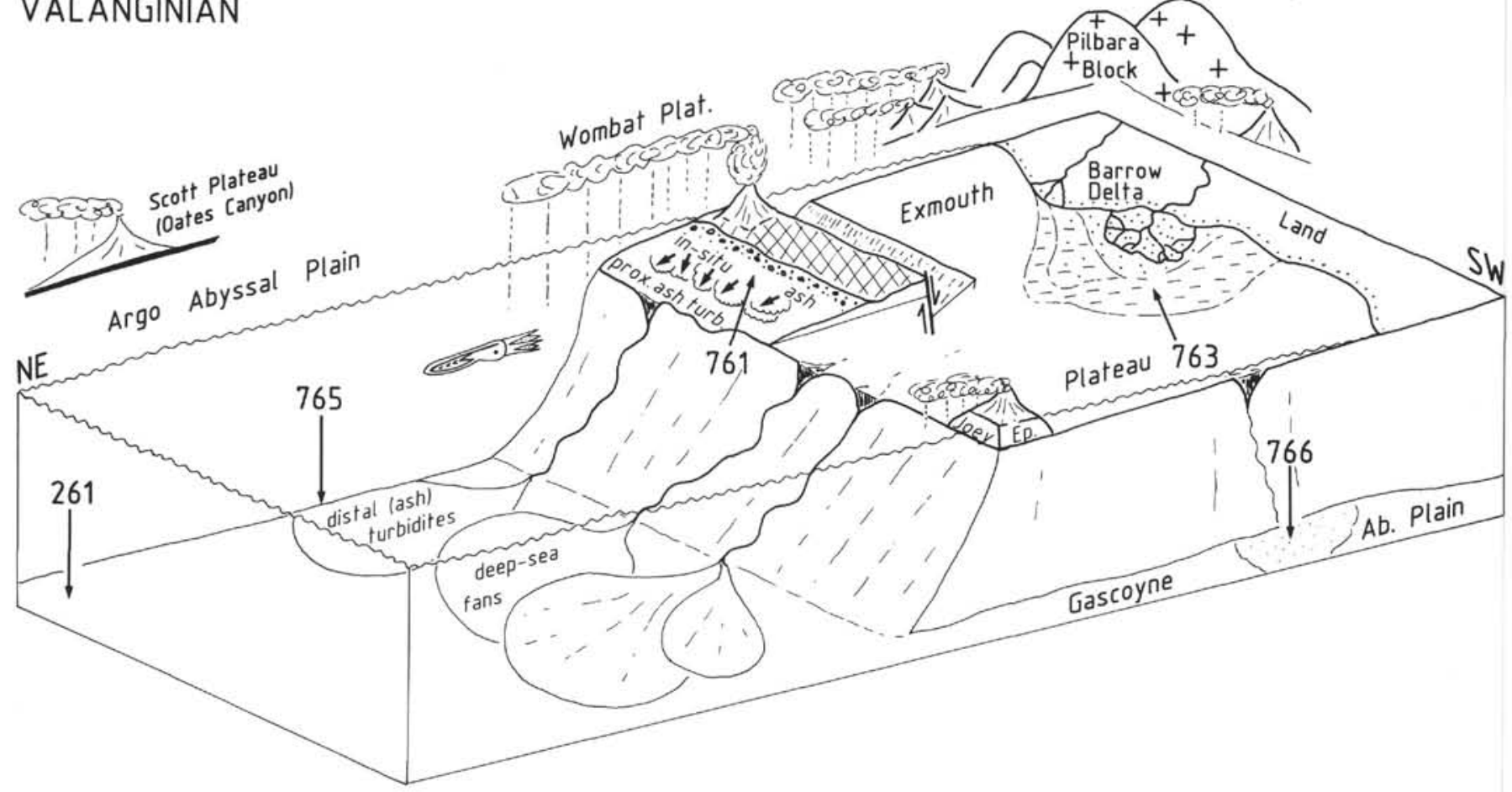

Figure 6. Schematic paleogeographic sketch of the northwest Australian margin during the early Neocomian (see Figs. 2A and 2B). Not to scale. Potential volcanic source areas for bentonites are very speculative. 
According to a very rough estimate, the Wombat Plateau ashes have a cumulative thickness of about $3 \mathrm{~m}$ and a volume of the order of a few cubic kilometers (assuming an area of about $1000 \mathrm{~km}^{2}$ for the submerged part of the Wombat Plateau). This compares well with the volume of correlated ash turbidites in the Lau Basin (up to $>0.8 \mathrm{~km}^{3}$ ) and to the volume of ash erupted from Mount St. Helens in 1980 (1.3 $\left.\mathrm{km}^{3}\right)$.

The bentonites of Site 765 in the Argo Abyssal Plain are much thinner $(<13 \mathrm{~cm})$ than those from the Wombat Plateau and interpreted as partly air-fall ashes and partly distal ash turbidites. Most of the ash material was periodically redistributed downslope from the Wombat and northeastern Exmouth Plateau shelf by turbidity currents and finally deposited on large, distal deep-sea fans forming at the margins of the rapidly subsiding abyssal plain (see Thurow and von Rad, in press; Fig. 6).

We can also speculate how far from the source area our bentonites were deposited. From the maximum particle size of the glass shards and crystals and the $\mathrm{SiO}_{2}$ content of windtransported ash ("eolian fractionation") we can estimate the transport distances of air-fall ashes. The thick Wombat Plateau bentonites contain coarse particles (glass shards, feldspar crystals, and rock fragments) with a size of about $100 \mu \mathrm{m}$ (30-150 $\mu \mathrm{m})$, suggesting a transport distance of not more than a few tens to $200 \mathrm{~km}$ (Winkler et al., 1985; von Rad and Mühe, 1990).

\section{CONCLUSIONS}

1. Bentonites (i.e. "argillized" volcanic ash layers of dacitic to rhyolitic composition altered to smectite-dominated claystones) were discovered in Berriasian to Valanginian sediments of the Wombat Plateau (Site 761, hemipelagic “juvenile ocean" setting) of the Argo Abyssal Plain (Site 261, 765 , pelagic claystones, etc.) of the southern Exmouth Plateau (Site 763, shelfal prodelta mudstones) and of the easternmost Gascoyne Abyssal Plain (Site 766, hemipelagic sandy mudstones; Fig. 2).

2. A volcaniclastic origin of these bentonitic claystones was proven by (1) the abundance of well-ordered dioctahedral montmorillonite; (2) the presence of fresh to altered silicic glass shards of low-K dacitic to rhyolitic composition; (3) the presence of euhedral sanidine, clinopyroxene, and volcanic rock fragments; (4) a typical apatite and (slender) zircondominated heavy mineral association; and (5) a vitroclastic ultrafabric consisting of smectitized glass shards with the typical "honeycomb texture" of montmorillonite (Pl. 4).

3. Mineralogically and chemically, we distinguished (1) white, pink, light gray, pure smectite bentonites with a "waxy" or "soapy" appearance and a very homogeneous cryptocrystalline smectite matrix (water-free composition: $68.5 \% \mathrm{SiO}_{2}, 0.27 \%$ $\mathrm{TiO}_{2}, 19.1 \% \mathrm{Al}_{2} \mathrm{O}_{3}, .04 \%-1.1 \% \mathrm{Na}_{2} \mathrm{O}, 0.6 \% \mathrm{~K}_{2} \mathrm{O}$, and approximately $17 \% \mathrm{H}_{2} \mathrm{O}$ ); and (2) dark gray, gray, and brown impure bentonites, mixtures of volcanogenic smectite and pyroclastic grains with nonvolcanic (terrigenous and pelagic) components and a variable chemical composition.

4. Diagenetic alteration includes smectitization and zeolite authigenesis. Alteration of silicic glass shards proceeds from (1) more or less fresh (possibly hydratized) glass to (2) slightly altered (etched) glass with corrosion pits with incipient smectite authigenesis, to (3) moderately altered (smectitized) glass (with the shard shape generally intact), to (4) completely homogenized pure smectite bentonites without obvious vestiges of the original ashy material. Euhedral clinoptilolite, generally postdating smectite genesis, is the main zeolite mineral, precipitated in the open pore space (or replacing glass shards). Most of it might, however, be derived from the dissolution of opaline skeletons rather than from volcanic glass as parent material.

5. Explosive volcanic activity was associated with rifting, continental breakup, and the following rapid subsidence. Potential source areas which were volcanically active during the latest Jurassic to Neocomian (-Aptian) include (Figs. 2 and 6) the Wombat Plateau (?), Joey and Roo rises (northwestern extension of the Exmouth Plateau), Scott Plateau (Oates Canyon) east of Argo Abyssal Plain, and the Wallaby Plateau/ Cape Range Fracture Zone south of Exmouth Plateau.

Although the chemical composition of the ashes does not exclude a volcanic arc as a source area, plate tectonic and paleogeographic considerations (Fig. 2) make this an unlikely interpretation.

6. We speculate that westward-directed high-altitude trade winds transported silicic ash from these volcanic source areas to the Exmouth Plateau and the adjacent abyssal plains. The Wombat Plateau bentonites are explained as proximal ash turbidites because of their great thickness, color and size (?) grading, distinct lower and gradational upper contacts, and parallel- and cross-lamination. The total ash volume of the six to seven bentonite layers was a few cubic kilometers and the distance of the source area a few tens to $200 \mathrm{~km}$.

We have discovered vestiges of a major phase of volcanic activity with highly differentiated, alkali-rich, intermediate to silicic composition which are obviously associated with extensional tectonics and continental breakup. However, the exact nature and the magmatic-tectonic importance of this "post-breakup volcanism" is still poorly understood.

\section{ACKNOWLEDGMENTS}

The Deutsche Forschungsgemeinschaft (Bonn) supported this research by ODP grants ( $\mathrm{Ra} 191 / 10$, Wi 112/25). We are grateful to the following colleagues who helped us with their expertise: to Dr. P. Čepek (BGR, Hannover), Dr. T. Bralower (Miami, USA), and Dr. H. Keupp for nannoplankton and calcisphere determinations, Dr. J. Mutterlose (Hannover) for belemnite identifications, and Dr. E. Kristan-Tollmann for the study of a crinoid calice in the belemnite sand of Site 761; to Dr. R. Boyd (GEOMAR, Kiel) for his help in interpreting wireline logs and his input to Figure 2, to Dr. V. Marchig (BGR, Hannover) for her help in interpreting the geochemistry, to Dr. R. Petschick (AWI, Bremerhaven) for detailed XRD analyses and interpretations (see Fig. 4), and to Dr. W. Zimmerle (Celle) for his advice on how to tackle the investigation of bentonites. Dr. Zinkernagel (Bochum) supplied the excellent thin sections and Mr. Hüttemann (Tübingen) helped with his expertise in SEM/EDX analysis. Dr. U. Röhl (BGR, Hannover) helped with the data collection and the drawing of Figure 6. Mr. Requard and J. Lodziak (both BGR, Hannover) provided the XRF analyses. H. Karmann (BGR) drafted the figures, T. Hointza (BGR) helped with sample processing, and E. Müller (BGR) typed the manuscript. The manuscript was kindly reviewed by Drs. U. Röhl (Hannover), T. Bralower (Miami), D. Rea (Ann Arbor, MI), and T. Vallier (Menlo Park, CA).

\section{REFERENCES}

Barber, P. M., 1982. Paleotectonic evolution and hydrocarbon genesis of the central Exmouth Plateau. APEA J., 22:131-144.

Boote, D.R.D., and Kirk, R. B., 1989. Depositional wedge cycles on evolving plate margin, western and northwestern Australia. $A A P G$ Bull., 73:216-243.

Bradshaw, M. T., Yeates, A. N., Beynon, R. M., Brakel, A. T., Langford, R. P., Totterdell, J. M., and Yeung, M., 1988. Paleogeographic evolution of the North West Region. In Purcell, P. G., 
and Purcell, R. R. (Eds.) The North West Shelf, Australia: Proc. Pet. Expl. Soc. Aust. Symp., 29-54.

Carey, S. H., and Sigurdson, H., 1984. A model of volcanogenic sedimentation in marginal basins. In Kokelaar, B. P., and Howells, M. F. (Eds.), Margin Basin Geology. Geol. Soc. London, 37-58.

Cook, P. J., Veevers, J. J., Heirtzler, J. R., and Cameron, P. J., 1978. The sediments of the Argo Abyssal Plain and adjacent areas, northeast Indian Ocean. BMRJ. Aust. Geol. Geophys., 3:113-124.

Fisher, R. V., and Schmincke, H.-U., 1984. Pyroclastic Rocks: New York (Springer-Verlag).

Fullerton, L. G., Sager, W. W., and Handschumacher, D. W., 1989. Late Jurassic-Early Cretaceous evolution of the eastern Indian Ocean adjacent to Northwest Australia. J. Geophys. Res., 94:2937-2953.

Gradstein, F. M., Gibling, M. R., Jansa, L. F., Kaminski, M. A., Ogg, J. G., Sarti, M., Thurow, J. W., von Rad, U., and Westermann, G.E.G., 1989. Mesozoic stratigraphy of Thakkhola, Central Nepal. Cent. Mar. Geol., Dalhousie Univ., Halifax, Canada, Lost Ocean Expedition, Spec. Rep. 1.

Grim, R. E., and Güven, N., 1978. Bentonites: Geology, Mineralogy, Properties, and Uses: Amsterdam (Elsevier).

Haq, B. U., Hardenbol, J., and Vail, P. R., 1987. Chronology of fluctuating sea levels since the Triassic. Science, 235:1156-1167.

Haq, B. U., von Rad, U., O'Connell, S., et al., 1990. Proc. ODP, Init. Repts., 122: College Station, TX (Ocean Drilling Program).

Hinz, K., Beiersdorf, H., Exon, N. F., Roeser, H. A., Staff, H.M.J., and von Stackelberg, U., 1978. Geoscientific investigations from the Scott Plateau off Northwest Australia to the Java Trench. BMR J. Aust. Geol. Geophys., 3:319-340.

Hocking, R. M., Moors, H. T., and Van Der Graaff, W.J.E., 1987. The geology of the Carnarvon Basin, W.A. Bull. Geol. Surv. West. Aust., 133.

Huber, N. K., and Rinehart, D. D., 1966. Some relationships between the refractive index of fused glass beads and the petrologic affinity of volcanic rock suites. Geol. Soc. Am. Bull., 77:101-110.

Kastner, M., and Stonecipher, S. A., 1978. Zeolites in pelagic sediments of the Atlantic, Pacific, and Indian oceans. In Sand, L. B., and Mumpton, F. A. (Eds.), Natural Zeolite: Occurrence, Properties, Use: New York (Pergamon Press), 199-218.

Konta, J., 1986. Textural variation and composition of bentonite derived from basaltic ash. Clays Clay Miner., 34:257-265.

Kopsen, E., and McGann, G., 1985. A review of the hydrocarbon habitat of the eastern and central Barrow-Dampier Sub-Basin, Western Australia. APEA J., 25:154-175.

Le Bas, M. J., Le Maitre, R. W., Streckeisen, A., and Zanettin, B., 1986. A chemical classification of volcanic rocks based on the Total Alkali-Silica Diagram. J. Petrol., 27:745-750.

Ludden, J., Gradstein, F. M., et al., 1990. Proc. ODP, Init. Repts., 123: College Station, TX (Ocean Drilling Program).

Mutterlose, J., in press. Early Cretaceous belemnites from the East Indian Ocean and their paleobiogeographic implications. In Gradstein, F. M., Ludden, J. N., et al., Proc. ODP, Sci. Results, 123: College Station, TX (Ocean Drilling Program).

Ogg, J. G., Kodama, K., and Wallick, B. P., in press. Lower Cretaceous magnetostratigraphy and paleolatitudes off Northwest Australia (ODP Site 765 and DSDP Site 261, Argo Abyssal Plain, and ODP Site 766, Gascoyne Abyssal Plain). In Gradstein, F. M., Ludden, J. N., et al., Proc. ODP, Sci. Results, 123: College Station, TX (Ocean Drilling Program).

Peccerillo, A., and Taylor, S. R., 1976. Geochemistry of Eocene calc-alkaline volcanic rocks from the Kastamonu area, northern Turkey. Contrib. Mineral. Petrol., 58:63-81.

Peirce, J., Weissel, J., et al., 1989. Proc. ODP, Init. Repts., 121: College Station, TX (Ocean Drilling Program).
Pupin, J. P., 1980. Zircon and granite petrology. Contrib. Mineral. Petrol., 73:207-220.

Riech, V., and von Rad, U., 1979. Silica diagenesis in the Atlantic Ocean: diagenetic potential and transformations. In Talwani, M., Hay, W., and Ryan, W.B.F. (Eds.), Deep Drilling Results in the Atlantic Ocean: Continental Margins and Paleoenvironment: Am. Geophys. Union, Maurice Ewing Ser., 3:315-340.

Samson, S. D., Patchett, P. J., Roddick, J. C., Parrish, R. R., 1989. Origin and tectonic setting of Ordovician bentonites in North America: isotopic and age constraints. Geol. Soc. Am. Bull., 101:1175-1181.

Schmincke, H. U., 1989. Pyroklastische Gesteine. In Füchtbauer et al. (Eds.), Sedimente und Sedimentgesteine: Stuttgart (Schweizerbart), 731-778.

Thurow, J., and von Rad, U., in press. Early Neocomian bentonites of Leg 123 sites. In Gradstein, F. M., Ludden, J. N., et al., Proc. ODP, Sci. Results, 123: College Station, TX (Ocean Drilling Program).

Towner, R. R., and Gibson, D. L., 1983. Geology of onshore Canning Basin, Western Australia. BMR Bull., 215.

Veevers, J. J., 1988. Morphotectonics of Australia's northwestern margin. In Purcell, P. G., and Purcell, R. R. (Eds.), The North West Shelf Australia. Proc. Pet. Expl. Soc. Aust. Symp., 173-187.

Veevers, J. J., and Cotterill, D., 1978. Western margin of Australia: evolution of rifted arch system. Geol. Soc. Am. Bull., 89:337-355.

Veevers, J. J., Heirtzler, J. R., et al., 1974. Init. Repts. DSDP, 27: Washington (U.S. Govt. Printing Office).

von Rad, U., and Exon, N. F., 1983. Mesozoic-Cenozoic sedimentary and volcanic evolution of the starved passive continental margin off northwest Australia. In Watkins, J. S., and Drake, C. L. (Eds.), Studies in Continental Margin Geology: AAPG Mem., 34:253281.

von Rad, U., and Mühe, R., 1990. Mineralogy, chemical composition and origin of ash layers and pumice in sediments from the Lau and North Fiji Basins (SW Pacific, SO-35 Cruise). Geol. Jahrb., D92:279-339.

von Rad, U., Thurow, J., Haq, B. U., Gradstein, F., Ludden, J., and ODP Leg 122/123 Shipboard Scientific Parties, 1989. Triassic to Cenozoic evolution of the NW Australian continental margin and the birth of the Indian Ocean (preliminary results of ODP Legs 122 and 123). Geol. Rundsch., 78:1189-1210.

White, R., 1989. Volcanism and igneous underplating in sedimentary basins and at rifted continental margins. In Price, R. A. (Ed.), Origin and Evolution of Sedimentary Basins and Their Energy and Mineral Resources. Int. Union Geol. Geophys., Geophys. Monogr. 48, Vol. 3:125-127.

Winchester, J. A., and Floyd, P. A., 1977. Geochemical discrimination of different magma series and their differentiation products using immobile elements. Chem. Geol., 20:325-343.

Winkler, W., Galetti, G., and Maggetti, M., 1985. Bentonite im Gurnigel-, Schlieren- und Wägital-Flysch: Mineralogie, Chemismus, Herkunft. Eclogae Geol. Helv., 78:545-564.

Zimmerle, W., 1989. Vestiges of volcanic activity in Cretaceous sediments of Europe. In Wiedmann, J. (Ed.), Cretaceous of the Western Tethys. Proc. 3rd Inter. Cretaceous Symp., Tübingen 1987, 951-987.

Zimmerle, W., and Gaida, K.-H., 1980. Identification of ancient tuffs and volcanic components in progressively altered ancient argillaceous sediments. A discussion. Int. Assoc. Sedimentol., First Europ. Meet. Bochum 1980, 251-254. (Abstract)

Date of initial receipt: 11 June 1990

Date of acceptance: 4 February 1991

Ms 122B-185 

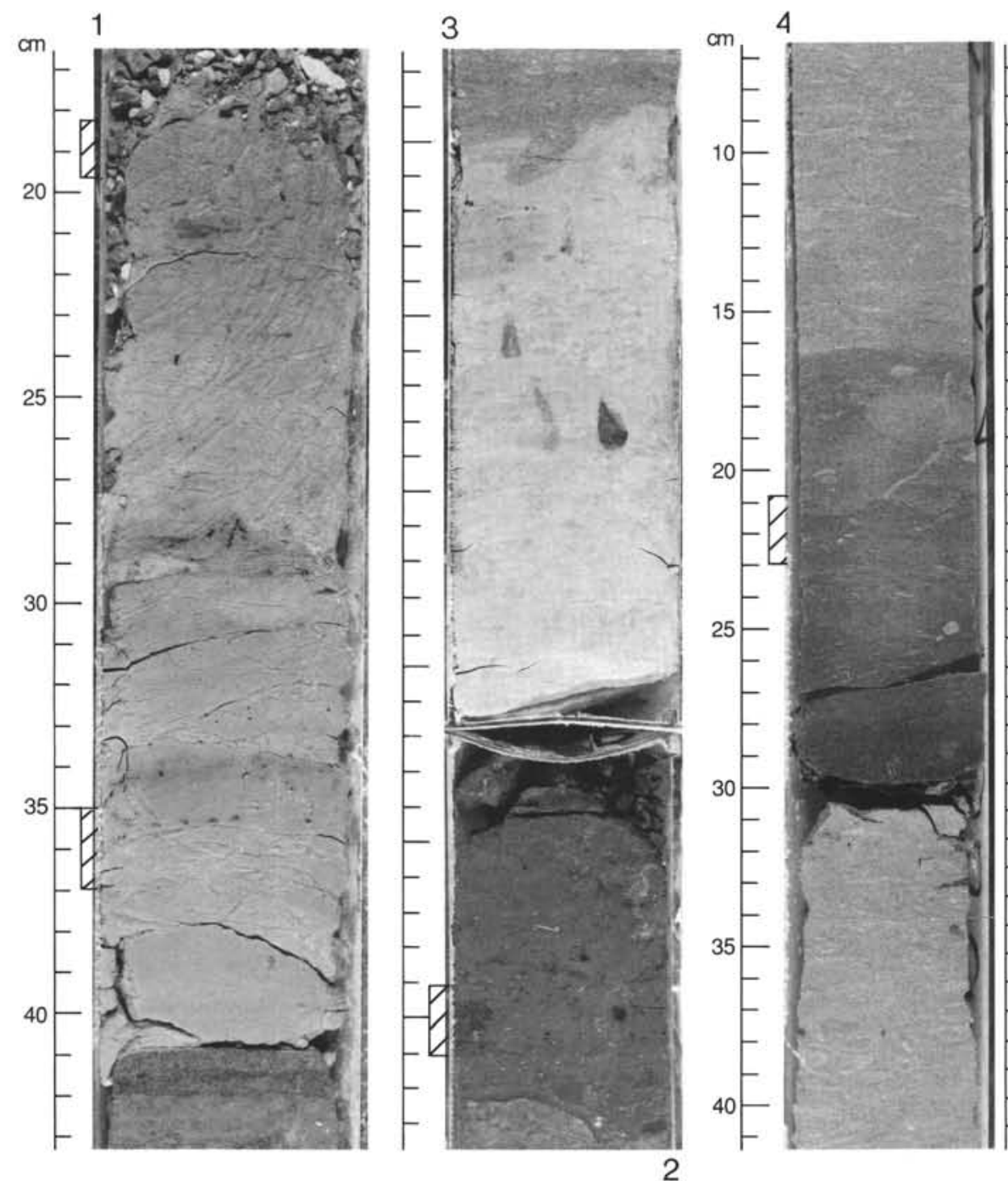

5

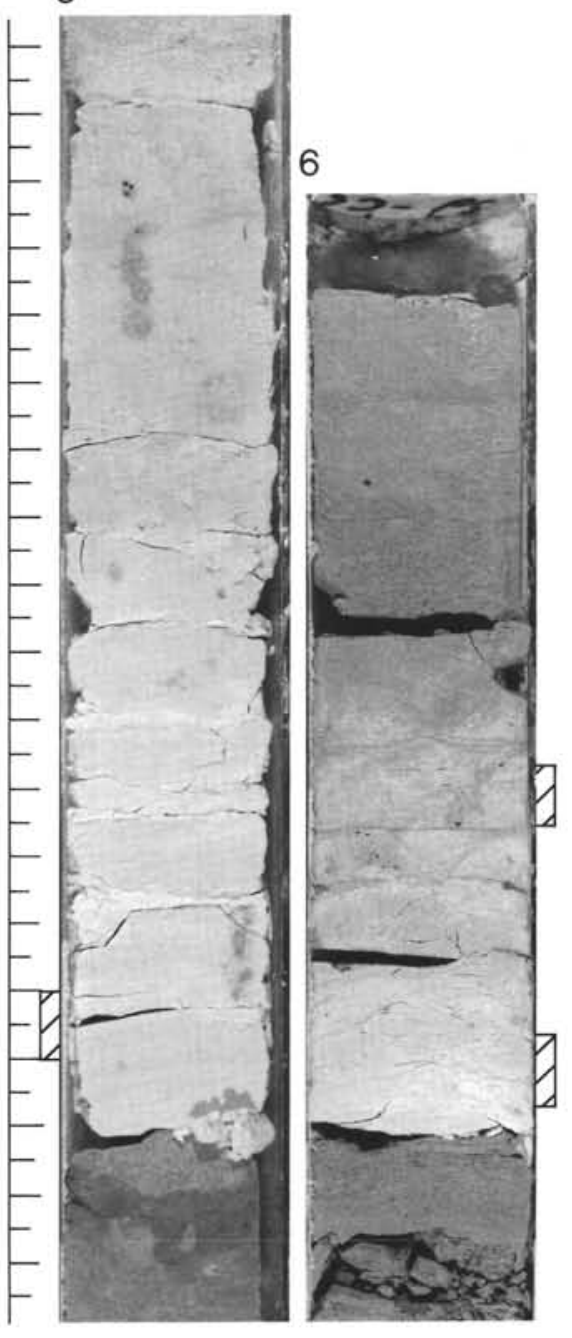

Plate 1. Close-up core photographs of lower Neocomian bentonite layers from Leg 122, Site 761, Wombat Plateau (see text). Location of samples shown by dark lines. 1. Interval 122-761C-10R-1, 16.5-43.5 cm. Bentonite B1 (base: pink, massive, waxy, pure smectite bentonite; top: light brownish gray impure bentonite). Note very sharp lower contact overlying light yellowish brown sandy calcisphere chalk. 2. Interval 122-761C-9R-CC, 0-12 cm. Bentonite B2: brown, very impure smectite bentonite, rich in volcaniclastics. Note sharp lower boundary to underlying calcisphere nannofossil chalk. 3. Interval 122-761C-9R-2, 2.7-21.5 cm. Bentonite B3: "white" pure bentonite grading upward into mottled pale yellow bentonite. Indistinct upper contact with burrow from overlying pale olive calcisphere chalk. 4. Interval 122-761C-8R-2, $6.5-41.5 \mathrm{~cm}$. Bentonite B4: very impure smectite-rich bentonitic clay (base: very dark gray, grading upward into gray, mottled with to pale yellow calcisphere chalk). Over- and underlain by pale yellow calcisphere nannofossil chalk. 5. Interval 122-761C-8R-1, 102-141 cm. Bentonite B5: base is very white, pure smectite bentonite, grading upward into light gray impure bentonite with gradual transition to calcisphere chalk (rotary coring). 6. Interval 122-761B-29R-CC, 20-33 cm. Bentonite B5 (same as in (5), note poorer recovery by XCB coring). Sharp basal contact and gradual transition to overlying calcisphere chalk. 
$\mathrm{cm}$

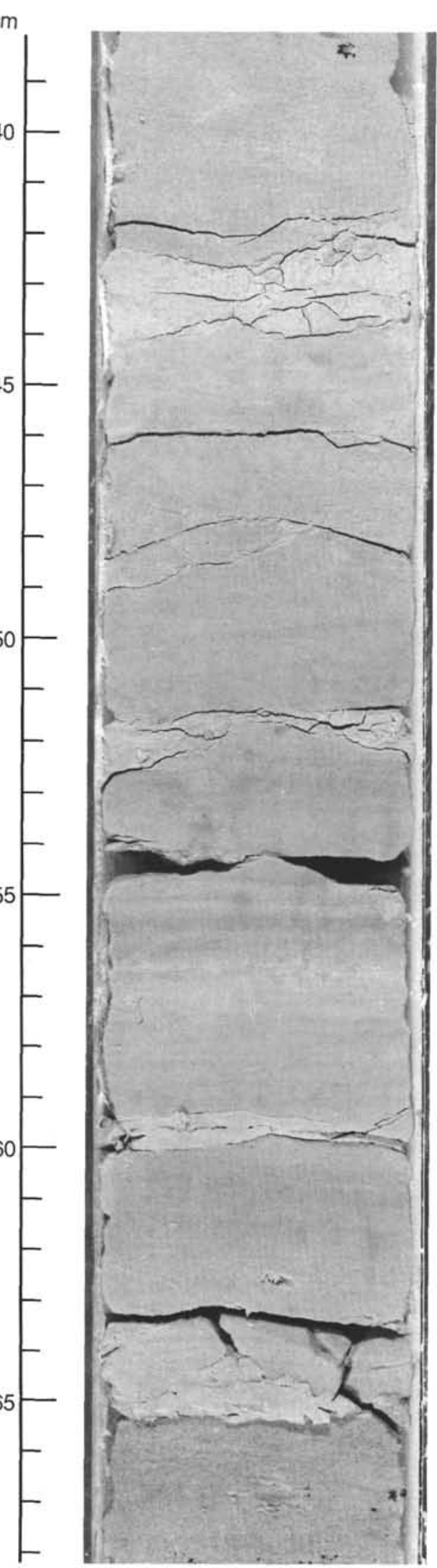

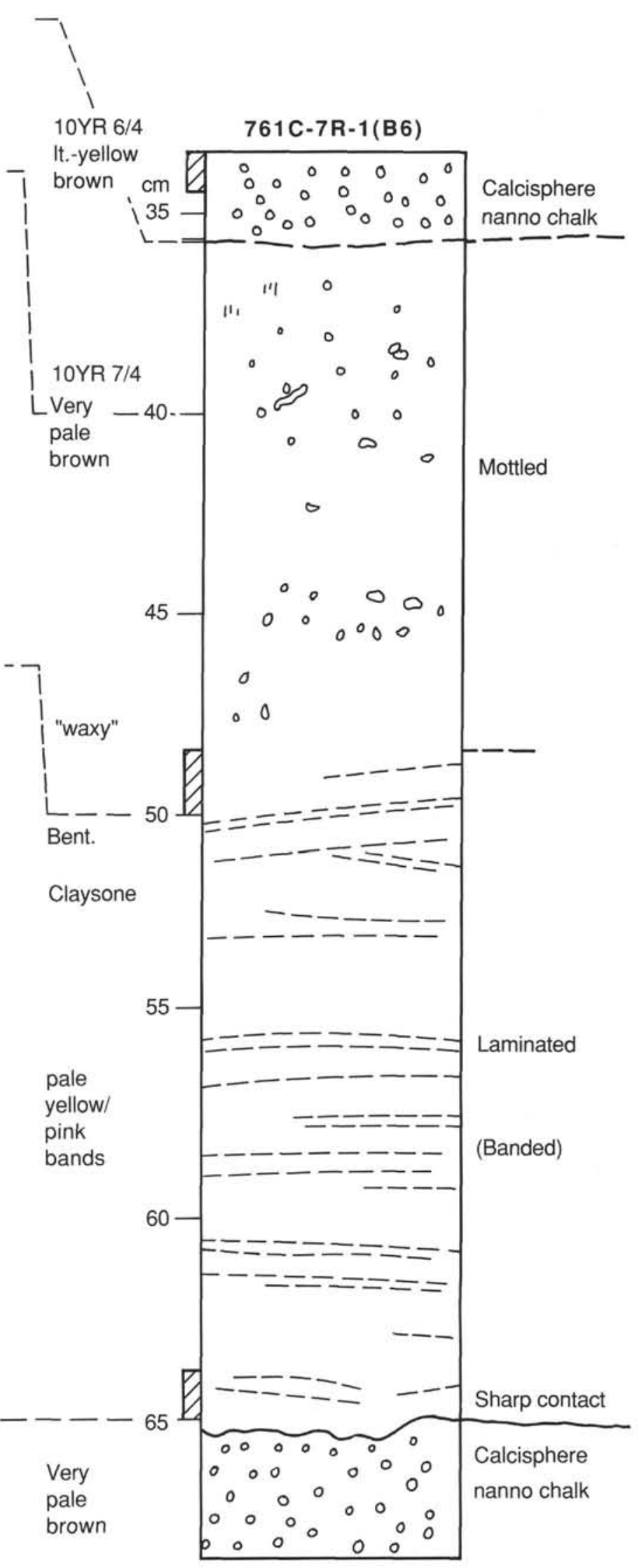

Plate 2. Interval 122-761C-7R-1, 34-68 cm. Core photo and line drawing of bentonite B6 with parallel- and indistinct cross-lamination in lower half and mottling in upper half. This bentonite is interpreted as a proximal ash turbidite. 

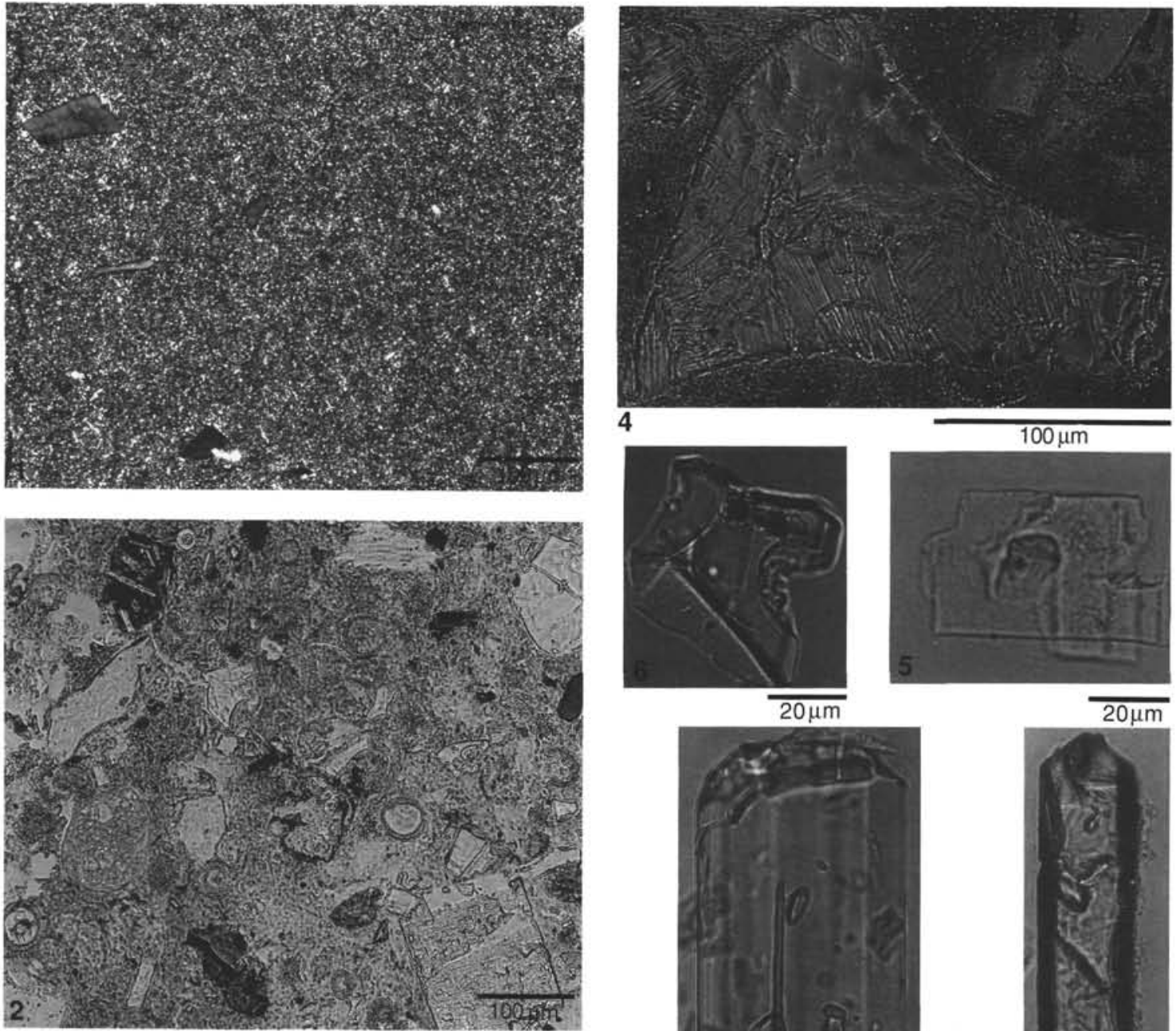

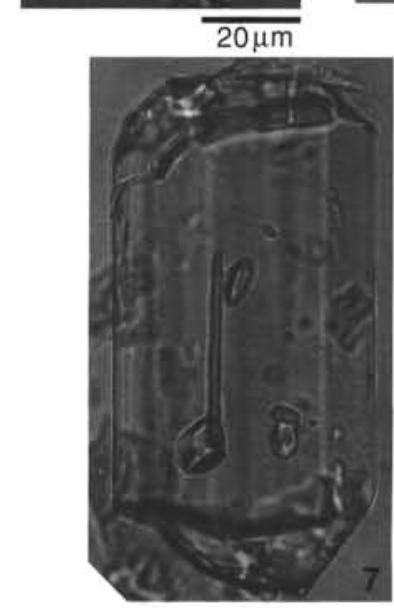

$50 \mu \mathrm{m}$

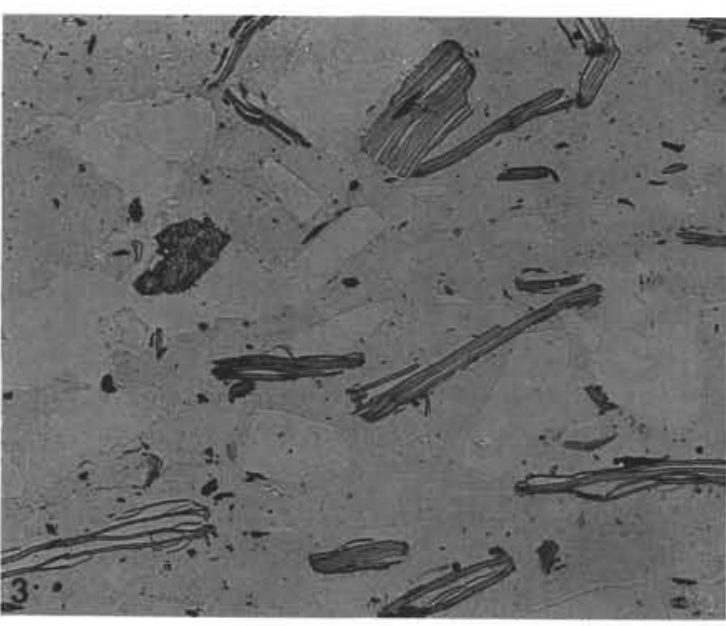

$50 \mu \mathrm{m}$

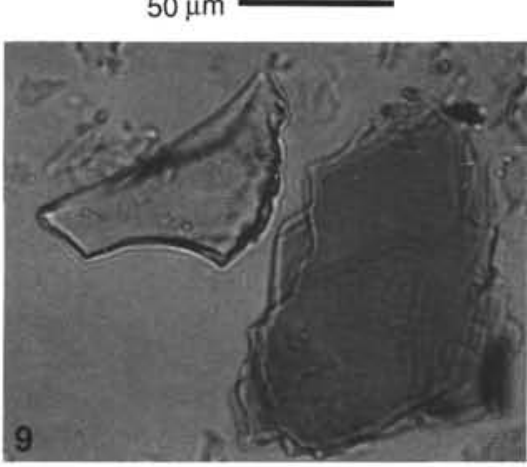

$50 \mu \mathrm{m}$

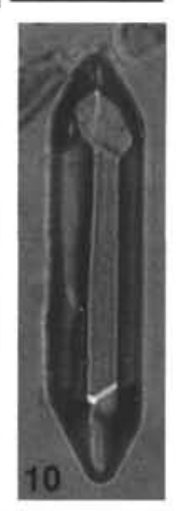

$50 \mu \mathrm{m}$

Plate 3. Thin-section photomicrographs of Leg 122 bentonites. 1. Sample 122-761C-8R-1, 131-133 cm (B5). Pure bentonite with homogeneous cryptocrystalline smectite matrix with pinpoint extinction (crossed nicols) and traces of quartz, feldspar, phyllosilicates, and calcispheres. 2. Sample 122-761C-9R-CC, 7-9 cm (B2). Very impure, heterogeneous sandy bentonitic clay. Note quartz, opaque volcanic rock fragments, glass shards, carbonate crystal, calcispheres, and sponge spicules. 3. Sample 122-763C-29R-4, 102-104 cm. Very heterogeneous, biotite-, quartz-, and feldspar-rich bentonitic claystone. 4. Sample 122-761C-9R-CC, 7-9 cm (B3). Zeolitized volcanic glass shard (clinoptilolite). 5. Same sample as (4) (B3). Euhedral, volcanogenic(?) sanidine. 6. Same sample as (4) (B3). Silicic bubble-wall glass shard. 7. Same sample as (3). Euhedral apatite with inclusions. 8. Sample 122-761C-10R-1, 35-37 cm (B1). Long-prismatic zircon, rich in inclusions. 9. Same sample as (7). Basaltic glass shard and biotite flake. 10. Same sample as (7). Long-prismatic, euhedral zircon. 

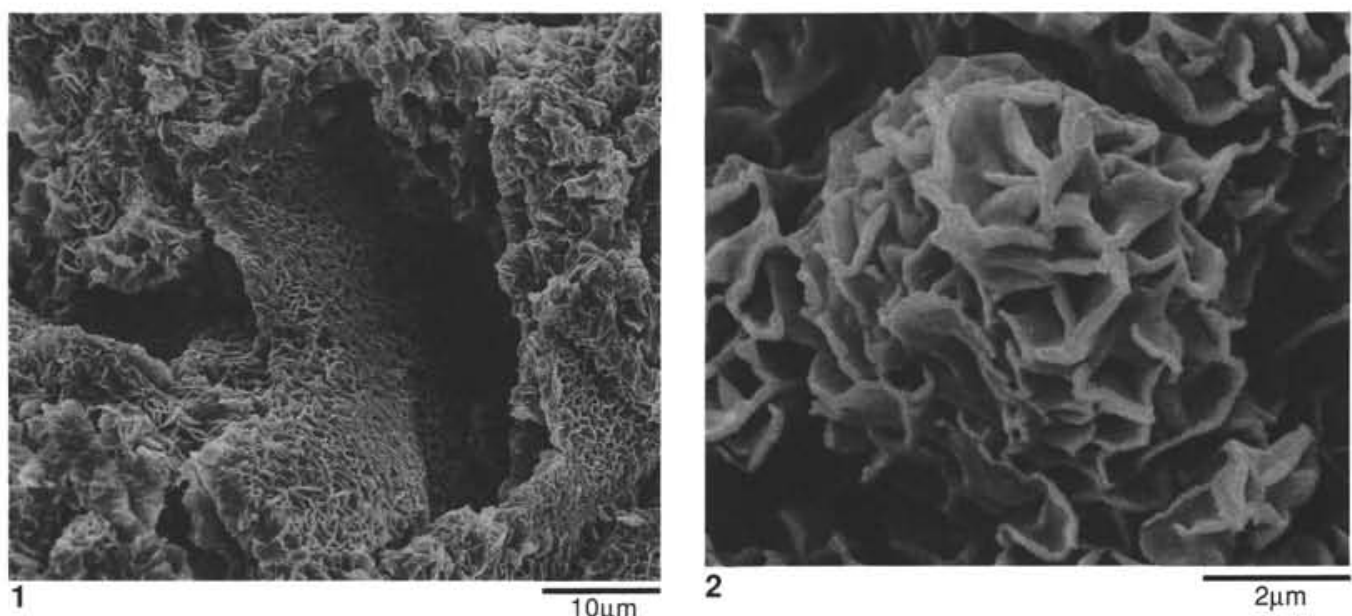

$10 \mu \mathrm{m}$

2

$2 \mu \mathrm{m}$
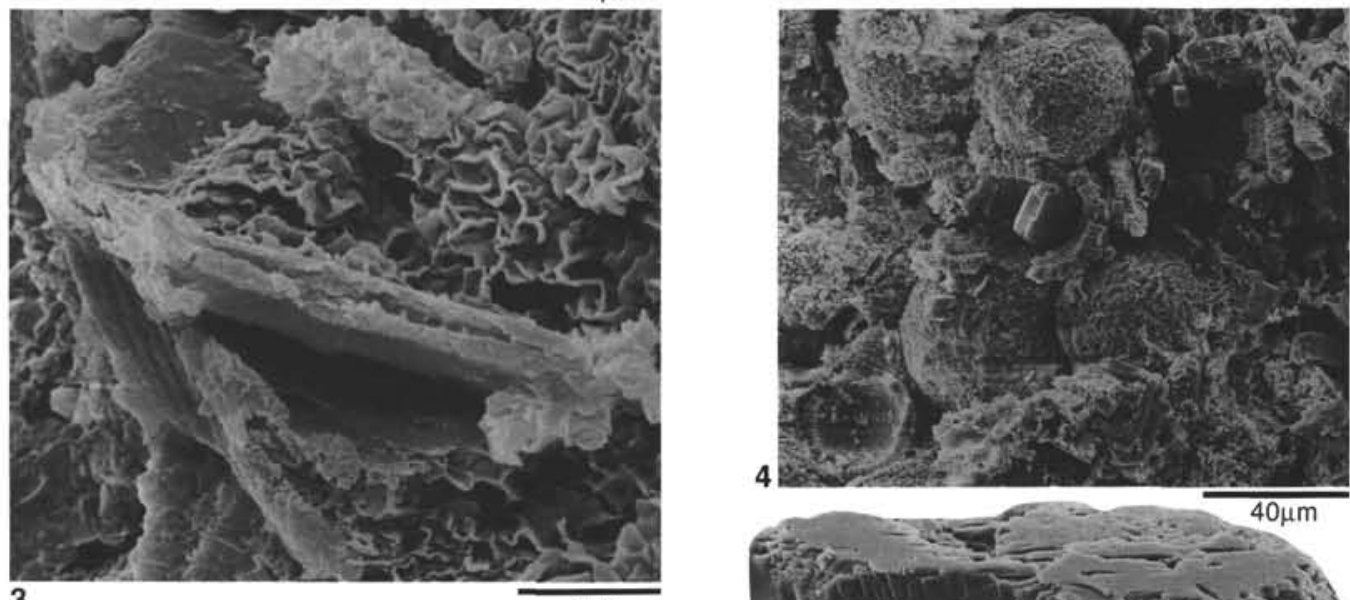

4

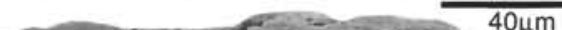

3

$4 \mu \mathrm{m}$

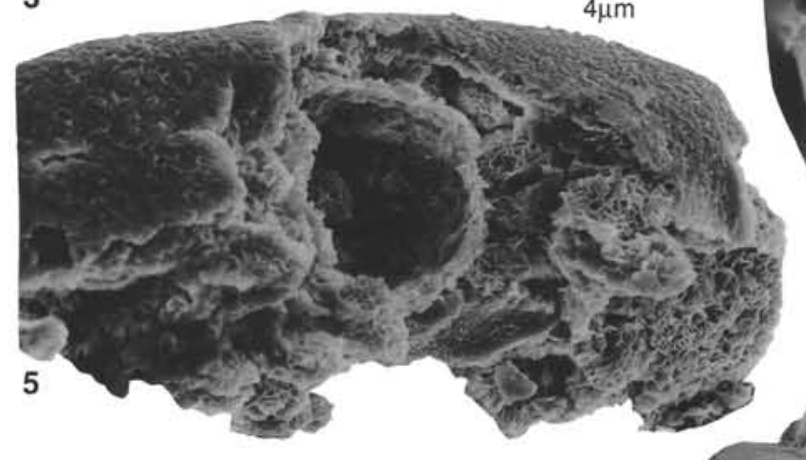

$20 \mu \mathrm{m}$

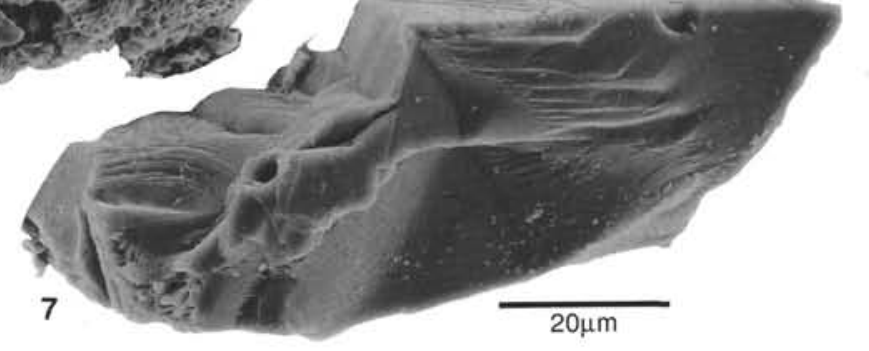

Plate 4. SEM photomicrographs of Leg 122 bentonites. 1. Sample 122-761C-9R-2, 18-19 cm (SEM 57-437; B3): smectitereplaced glass shards in pure smectite bentonite ("hyaloclastic fabric"). 2. Sample 122-761C-10R-1, 18-19 cm (SEM 57-454; B1). Spherical smectite aggregates with honeycomb structure in pure bentonite. 3. Sample 122-761C-9R-CC, 7-9 cm (SEM 57-442; B2). V-shaped, partly smectite-replaced volcanic glass shard in impure bentonite. 4. Sample 122-761C-8R-1, 86 (SEM 57-405; B5). Impure bentonite (top of layer) with calcispheres, authigenic clinoptilolite, and smectite. 5. Sample 122-761C9R-2, 18-19 cm (SEM 57-471; B3). Smectite-replaced glass shard with large vesicle. 6. Sample 122-761C-9R-2, 18-19 cm (SEM 57-469; B3). Euhedral sanidine in pure bentonite (proven by EDX). 7. Sample 122-761C-9R-CC, 7-9 cm (SEM 57-447; B2). Silicic volcanic glass shard (EDX: Si-rich, small proportions of $\mathrm{Al}, \mathrm{Ca}$, and $\mathrm{Na}$ ). 